\title{
Selection of an Industrial Natural-Gas-Fired Advanced Turbine System - Task 3A
}

\author{
Topical Report \\ May 1997
}

By

Gary M. Holloway

\section{RECEIVED \\ FFR 131998 \\ OSTI}

\section{Work Performed Under Contract No.: DE-AC21-93MC30244}

For

U.S. Department of Energy

Office of Fossil Energy

Federal Energy Technology Center

Morgantown Site

P.O. Box 880

Morgantown, West Virginia 26507-0880

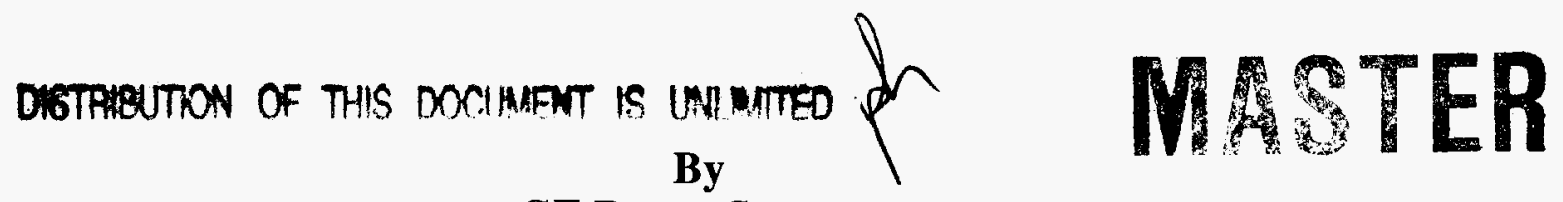

GE Power Systems

1 River Road

Schenectady, New York 12345 


\section{Disclaimer}

This report was prepared as an account of work sponsored by an agency of the United States Government. Neither the United States Government nor any agency thereof, nor any of their employees, makes any warranty, express or implied, or assumes any legal liability or responsibility for the accuracy, completeness, or usefulness of any information, apparatus, product, or process disclosed, or represents that its use would not infringe privately owned rights. Reference herein to any specific commercial product, process, or service by trade name, trademark, manufacturer, or otherwise does not necessarily constitute or imply its endorsement, recommendation, or favoring by the United States Government or any agency thereof. The views and opinions of authors expressed herein do not necessarily state or reflect those of the United States Government or any agency thereof. 


\section{TASK 3 - GAS FUELED ADVANCED TURBINE SYSTEM SELECTION}

\subsection{TASK OBJECTIVES}

Identify a gas-fueled turbine and steam system which will meet the program goals for efficiency and emissions.

\subsection{TECHNICAL GOALS AND REQUIREMENTS}

Goals for the Advanced Turbine System Program(ATS) where outlined in the statement of work for five basic categories:

- Cycle Efficiency

- - System heat rate to have a $15 \%$ improvement over 1991 vintage systems being offered to the market

- Environmental

No post-combustion devices while meeting the following parameter targets:

1. Nitrous Oxide (NOx) emissions to equal 8 parts per million dry (ppmd) with $15 \%$ oxygen.

2. Carbon monoxide (CO) and unburned hydrocarbon (UHC) emissions to equal 20 parts per million(ppmd) each.

- Cost

Cost of electricity to be 10 percent less when compared to similar 1991 systems.

\section{- Fuel Flexibility}

Have to ability to burn coal or coal derived fuels without extensive redesign.

- Reliability, Availability, Maintainability

Reliability, availability and maintainability must be comparable to modern advanced power generation systems.

For all cycle and system studies, analyses were done for the following engine system ambient conditions:

- Temperature $\quad 59 \mathrm{~F}$

- Altitude Sea Level

- Humidity $\quad 60 \%$

For the 1991 reference system, GE Aircraft Engines used its LM6000 engine product offering for comparison of the Industrial System parameters developed under this program. The LM6000 engine parameters are listed in Table 3.1. 
Table 33.1

(ISO) Shaft Output (MW) 40.75

Heat Rate (Btu/SHP-Hr) LHV $\quad 6,355$

Simple Cycle Efficiency (\%) $\quad 40.0$

Exhaust Gas Flow 274

Exhaust Gas Temperature (deg F) 869

Combined Cycle Output (Mw) $\quad 52.4$

Combined Cycle Efficiency (\%) $\quad 51.5$

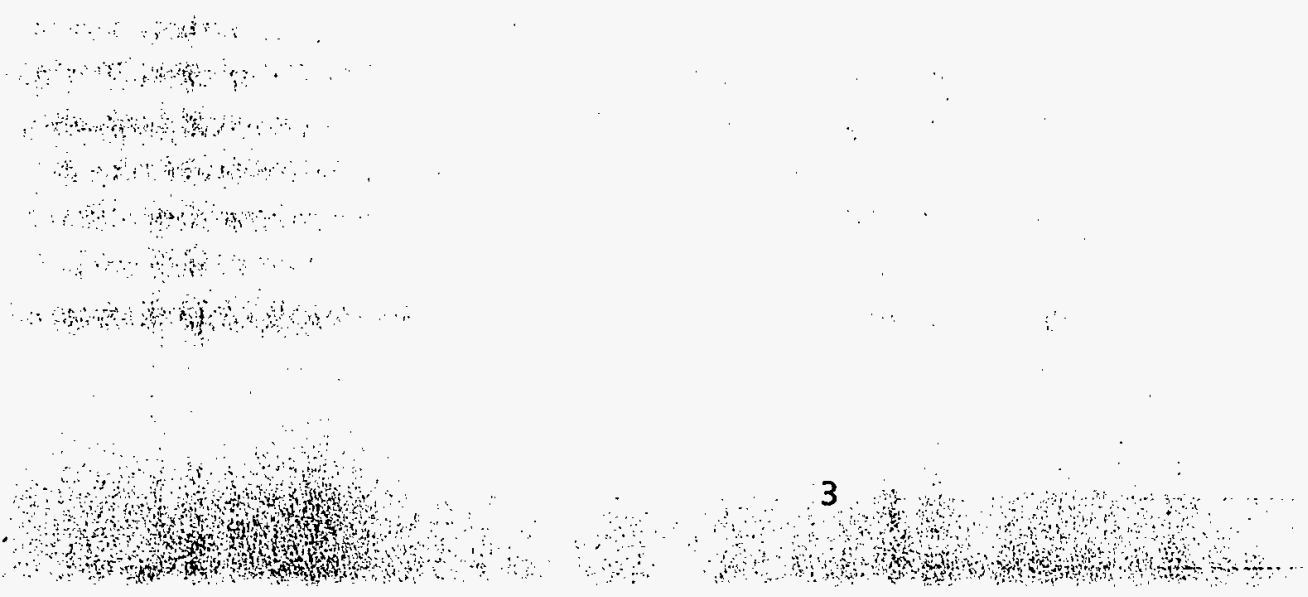




\subsection{CYCLE ANALYSIS}

Derivatives of simple and combined cycle performance were determined with respect to gas turbine component performance and cycle parameters, turbocooler circuit airflows, and bottoming cycle performance. The results determine ATS performance sensitivity to thermodynamic inputs and highlight components and parameters critical to achieving project goals.

\section{Cycle Variables}

The derivatives were determined using the configuration shown schematically in Figure 3.2.1 with the variables indicated. This is the direct drive, turbo-cooled, 1.75 booster pressure ratio, 2700F firing temperature design. The compressor size and speed are fixed at levels consistent with GE90 sea level static operation at the $88,800 \mathrm{lb}$. thrust level. All cases were designed to constant inlet and exhaust (stack) pressure losses. LP shaft speed was held at 3,600 rpm.

Derivatives were calculated for emissions, thermal efficiency, power output and high-pressure turbine flow function (HPTFF). Emission derivatives reflect values estimated based on flame temperature only. Thermal efficiency and power output derivatives were calculated for both simple and combined cycle systems. Combined cycle derivatives are calculated from a simplified three pressure level, non-reheat, steam cycle method. Also, HPTFF derivatives were calculated, because changes in HPT size are constrained by the need to use GE90 hardware. Baseline values of the independent variables are listed in Table 3.2.1.

The derivatives were calculated with respect to independent variables, including gas turbine and combined cycle component and cycle thermodynamic parameters, turbocooler circuit airflows, and inter-turbine reheat variables. Affected components and parameters are highlighted in Figure 3.2.1. Gas turbine variables include component efficiencies, pressure losses, and parasitic flows. Component efficiencies are defined as adiabatic except the booster, which is defined as polytropic. Pressure losses are defined by the ratio of component inlet to exit total pressure. Parasitic flows are defined by a fraction of HPC inlet physical flow. In addition, high-pressure compressor (HPC) inlet guide vane (IGV) angle, which regulates HPC flow and efficiency, was evaluated. Also, an estimated derivative on steam cycle efficiency was included. Thermodynamic (cycle) variables include booster pressure ratio and firing temperature. These independent variables are defined further and their baseline values are listed in the left columns of Table 3.2.2.

Turbocooler circuit flows include burner, HPT nozzle, and HPT Stage 1 rotor-cooled cooling air and turbocooler turbine discharge air. Turbocooler independent variables are listed along with source, sink, and baseline values in the top rows of Table 3.2.4. They are highlighted in Figure 3.2.1.

Performance derivatives were also examined for a reheat system which could be placed between the HPT and power turbine. The reheat system independent variables include burner firing temperature and pressure loss and power turbine cooling flow. These variables are listed in Table 3.2.5 and highlighted in Figure 3.2.1. 


\section{Cycle Results}

The results reflect partial derivatives calculated by varying independent variables separately and resizing the engine system around a fixed HPC flow size. The derivatives reflect a delta of one point $(1$ point $=0.01)$ in independent variable as defined in Table 2.2.2, column 2 , and Table 3.2.4, row 1, except for firing temperature (T41) and HPC IGV (STP25) setting. T41 derivatives are per degree Fahrenheit, and STP25 derivatives are per degree of vane angle. With these exceptions, the derivatives are defined by:

Combined and simple cycle thermal efficiency: HPT flow function:

NOx:

Combined and simple cycle power output: change in points per point

$\% \Delta$ W41R per point

$\Delta$ emission units per point

$\% \Delta$ horsepower per point

Table 2.2.4, listing derivatives with respect to turbocooler flows, contains additional data defining how the turbo-cooling system reacts to turbocooler flow changes. This is because turbocooler parameters must satisfy turbocooler operability requirements. For instance, the heat exchanger cannot function at an effectiveness greater than one, and the turbocooler turbine exit air pressure must be sufficient to re-enter the flowpath downstream of the HPT. For this reason, the following additional parameters are listed (these are not derivatives):

PS42: Static pressure downstream of HPT exit (turbocooler turbine sink pressure)

P80: Turbocooler turbine discharge manifold pressure (P80 is calculated such that cooled cooling flow is delivered at a manifold pressure of $\mathrm{P} 3$ )

\&HX: Heat exchanger effectiveness

Tfuel: Temperature of fuel entering combustor

Since the above parameters are not derivatives, the result listed is due to an increase of one point in flow fraction. These parameters also are highlighted in Figure 3.2.1.

Emissions Index derivatives are defined in Tables 3.2.2 and 3.2.4. Only firing temperature, cooling flow (cooled and uncooled), and parasitic flow derivatives are nonzero: these are the only variables affecting burner fuel to air ratio. Cooled burner/vane air has a strong impact, because this air is the only dilution air between burner and HPT rotor inlet. If T41 is fixed, this air sets the combustor flame temperature, hence emission level. The remaining parasitic flows have a -order effect: if T41 and dilution airflow are constant, dilution airflow becomes a larger fraction of total burner airflow as larger parasitic flows bypass the combustor. Hence, flame temperature increases to maintain $\mathrm{T} 41$ and emissions increase.

Combined cycle efficiency derivatives are influenced by a variety of parameters. HPC and LPT efficiencies dominate in component efficiency effects. Pressure loss results are about even, regardless of engine location. The parasitic flow results show that the derivative is a function of port location, with high-pressure air more costly than low-pressure air. Also, the further downstream the discharge port is, the greater the loss. For example, seventh stage balance piston air is more expensive than fourth stage air, and dumping seventh stage air in the stage two HPT rotor is less costly than if it were needed to cool the LPT rotor. Booster pressure ratio and T41 derivatives are small but can have significant influence if large changes occur. 
Increasing T41 and reducing booster PR have positive effects, but the selected values are dependent on other factors, such as cost, emissions, and size. The derivative on bottoming (steam) cycle efficiency simply reflects the contribution of the steam cycle to the total system power. That is, the derivative becomes stronger as steam cycle power becomes a larger fraction of total power.

Combined cycle power derivatives are impacted strongly by HPC, LPT, and gooseneck pressure loss, with other parameters having less effect. The HPC efficiency is strong due to the combined effects of reducing the HPC power requirement and dropping compressor discharge temperature (T3). Hence, these effects both provide more energy to the power turbine (HPT extracts less power) and increase burner temperature rise (T41-T3) as HPC efficiency increases. LPT performance provides for more simple cycle shaft power as LPT efficiency rises. Gooseneck pressure loss affects power output by increasing physical HPC airflow for a fixed HPC size. Hence, as pressure loss drops, airflow rises, and fuel flow (constant fuel to air ratio) and power output increase. In addition, parasitic flows affect $\mathrm{CC}$ power the same way they impact efficiency - high-pressure air is more costly than low-pressure air. Turbocooler circuit flows impact power in a similar way: any airflow bypassing the burner results in a loss of fuel flow, hence, power. Again, T41 and booster PR are influential but subject to other constraints.

The derivatives of simple cycle performance listed in Table 2.2.3 follow similar trends to CC derivative,s but are stronger. The derivatives are stronger, because cycle inefficiencies converted into waste heat are partially recovered in the bottoming cycle, which tends to reduce the effect of inefficiency on combine cycle performance. HPC and LPT efficiency have a strong impact on efficiency and power output. Gooseneck pressure loss drives power output, and parasitic and cooling flows drive emissions, efficiency, and power. In addition, although T41 and booster PR can have strong influences, these parameters are set by external considerations.

The HPC IGV setting derivatives show that small increases in efficiency are available but at a significant cost of power output. The baseline setting of zero degrees was picked mainly to maximize airflow and, thus, power.

Derivatives of HPTFF are also shown in Table 3.2.3, along with the corresponding influence on HPT efficiency. The idea here is that as flow function (area) deviates from its design value (about 30), HPT efficiency drops, as it becomes harder to adapt the GE90 HPT to the ATS. This effect is included in the simple and combined cycle efficiency derivatives.

The results of the reheat study are listed in Table 3.2.5. The primary benefit of reheat is it allows a higher gas turbine exit temperature (T5), which increases steam cycle efficiency. However, simple cycle efficiency falls. In addition, the reheat burner requires some sort of pressure drop, and a higher power turbine inlet temperature may require a cooled power turbine. For example, a reheat burner pressure drop of $6 \%$ requires 115 degrees of temperature rise to maintain constant CC efficiency. Two percent in cooling flow has about the same impact. This means a reheat system would require a critical balance between temperature rise, pressure drop, and cooling flows, if it is to have any benefit in system thermal efficiency. Emissions index for a reheat system was not evaluated. 


\section{Simple Cycle Recommendations}

It is important to remember that these derivatives are intended to provide guidance in selecting a final cycle design: they should allow for making small tradeoffs rationally. The derivatives will be accurate for small deviations in the baseline cycle defined in Table 3.2.1. However, accuracy will deteriorate with larger deviations. 


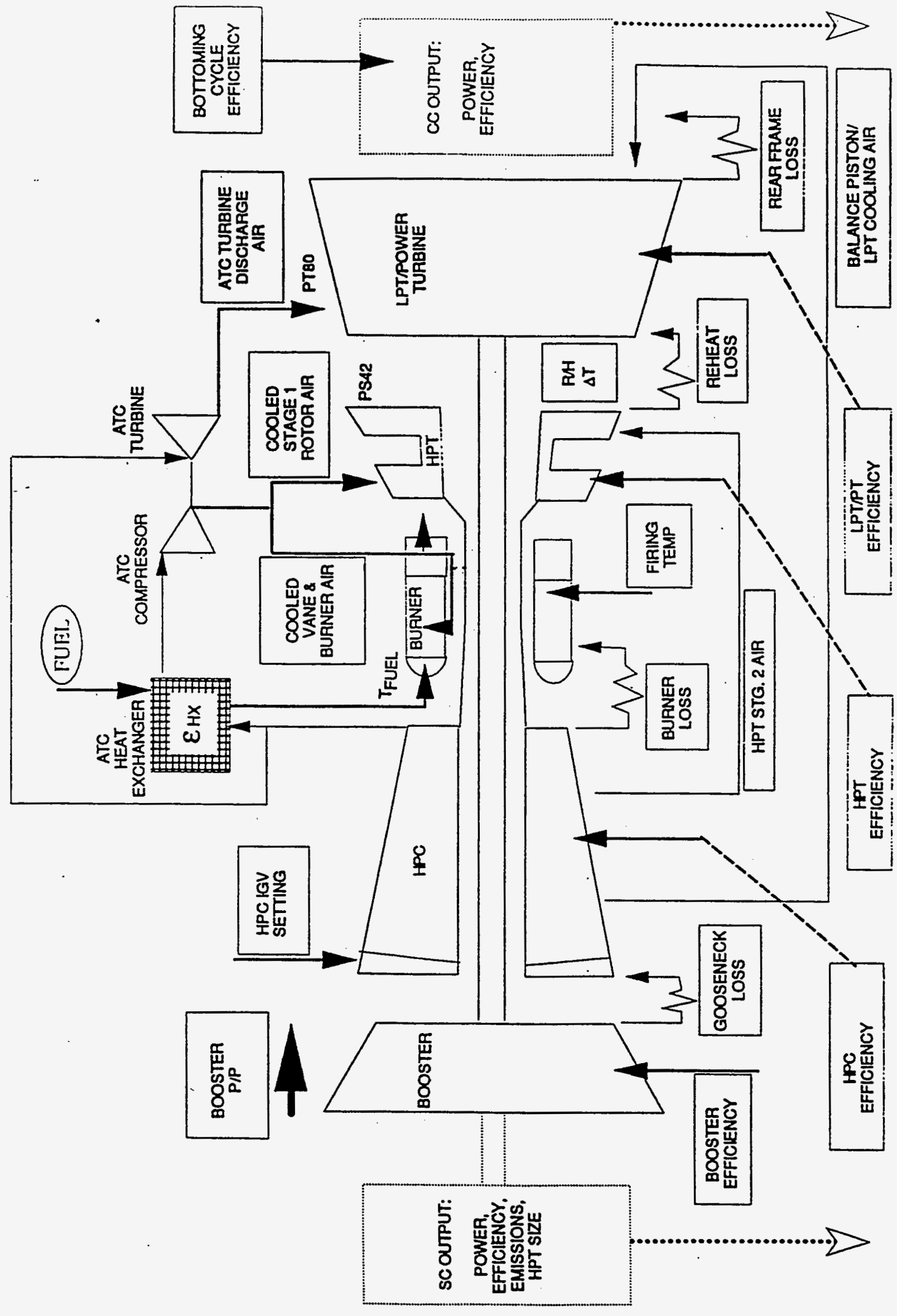

Figure 3.2.1. ATS Derivative Study Schematic and Variables 


\section{TABLE 3.2.1}

\section{Baseline ATS Preliminary Performance}

\begin{tabular}{ll} 
EINOX & 6.908 \\
$\eta_{C C}$ (PTS) & 58.4 \\
POWER CC (MW) & 97.0 \\
W41R & $32.2 \quad$ (GE90 +8\%) \\
$\eta_{S C}$ (PTS) & 46.55 \\
POWER & \\
$E_{\text {HX }}$ (MW) & 77.3 \\
THUel (F) & 0.830 \\
PS42 (PSI) & 965 \\
PT80 (PSI) & 109.1 \\
$\eta_{H P T}$ (PTS) & 178.9 \\
\hline
\end{tabular}


TABLE 3.2.2

Engine Component Performance Derivatives For 1 Point Delta

\begin{tabular}{|c|c|c|c|c|}
\hline COMPONENI & $\begin{array}{l}\text { BASELINE } \\
\text { YALUE }\end{array}$ & 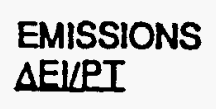 & $\begin{array}{l}\text { COMBINE CYCLE } \\
\text { An(PTSIPI }\end{array}$ & $\begin{array}{l}\text { POWER } \\
\% \triangle H P / P T\end{array}$ \\
\hline BOOSTER & $\eta_{p}=0.92$ & 0. & +0.063 & +0.367 \\
\hline HPC & $\eta_{a}=0.8536$ & 0 & +0.250 & +1.097 \\
\hline HPT & $\eta_{a}=0.9234$ & $0 \ldots$ & +0.197 & +0.329 \\
\hline LPT & $\eta_{\mathrm{a}}=0.9405$ & 0 & +0.274 & +0.462 \\
\hline BC EFFICIENCY & $\eta S T=0.85$ & 0 & +0.160 & +0.269 \\
\hline GOOSENECK & $P / P=0.982$ & 0 & +0.115 & +1.215 \\
\hline BUANER & $P / P=0.9467$ & 0 & +0.103 & +0.173 \\
\hline REAR FRAME & $P / P=0.96$ & 0 & +0.102 & +0.291 \\
\hline 4TH STG BP AIR & $W N W 25=0.0144$ & +0.034 & -0.272 & -1.601 \\
\hline TTH STG BP AIR & $W / W_{25}=0.0$ & +0.036 & -0.356 & -1.725 \\
\hline HPT STG 2 AIR & $W / W 25=0.0326$ & +0.036 & -0.199 & -1.464 \\
\hline BOOSTER PR & $P / P=1.75$ & 0 & -0.003 & +0.196 \\
\hline FIRING TEMP. & $\mathrm{T} 41=2700^{\circ} \mathrm{F}$ & $+0.033 / \mathrm{F}$ & $+0.010 \mathrm{PTS} /{ }^{\circ} \mathrm{F}$ & $+0.126 \% \% \mathrm{~F}$ \\
\hline HPC IGV SETTING & STP25 $=0$ & 0 & $+0.043 \mathrm{PTS} /{ }^{\circ}$ & $-0.984 \%$ \\
\hline
\end{tabular}




\section{TABLE 3.2.3}

\section{Simple Cycle Performance Derivatives}

\begin{tabular}{|c|c|c|c|c|c|}
\hline COMPONENII & $\begin{array}{l}\text { BASELINE } \\
\text { YALUE }\end{array}$ & $\begin{array}{l}\text { SIMPLE CYCLE } \\
\text { AIRISIIII }\end{array}$ & $\begin{array}{l}\text { SIMPLE CYCLE } \\
\% \triangle H P I P I\end{array}$ & $\begin{array}{l}\text { HPTFF } \\
\% \Delta W 41 B / P I\end{array}$ & $\Delta \mathrm{n}_{\mathrm{HPI}}$ (PTSYPI \\
\hline BOOSTER & $\eta_{p}=0.92$ & +0.083 & +0.440 & +0.104 & -0.020 \\
\hline HPC. & $\eta_{a}=0.8536$ & +0.344 & +1.424 & +0.011 & -0.088 \\
\hline HPT & $\eta_{a}=0.9234$ & +0.395 & +0.850 & 0 & - \\
\hline LPT & $\eta_{a}=0.9405$ & +0.550 & +1.183 & 0 & 0 \\
\hline BC EFFICIENCY & $\eta_{S T}=0.85$ & 0 & 0 & 0 & 0 \\
\hline GOOSENECK & $P / P=0.982$ & +0.203 & +1.015 & 0 & 0 \\
\hline BURNER & $P / P=0.9467$ & +0.208 & +0.450 & -1.025 & 0 \\
\hline REAR FRAME & $P / P=0.96$ & +0.206 & +0.442 & 0 & 0 \\
\hline 4TH STG BP AIR & $W / W 25=0.0144$ & -0.284 & -1.754 & -1.277 & +0.040 \\
\hline TTH STG BP AIR & $w / W 25=0.0$ & -0.447 & -2.078 & -1.260 & +0.058 \\
\hline HPT STG 2 AIA & $W N 25=0.0326$ & -0.134 & -1.419 & -1.271 & +0.058 \\
\hline BOOSTER PR & $P / P=1.75$ & +0.004 & +0.163 & +0.008 & -0.0016 \\
\hline FIRING TEMP. & $\mathrm{T} 41=2700^{\circ} \mathrm{F}$ & $+0.0036 \mathrm{PTS} /{ }^{\circ} \mathrm{F}$ & $+0.084 \% 1^{\circ} \mathrm{F}$ & $+0.020 \%{ }^{\circ} \mathrm{F}$ & $-0.0036 \% \% \mathrm{~F}$ \\
\hline HPC IGV SETIING & STP25 $=0$ & +0.035 PTS ${ }^{\circ}$ & $-0.533 \% /^{\circ}$ & $-0.281 \%$ & $-0.042 \%$ \\
\hline
\end{tabular}


TABLE 3.2.4

\section{Engine Performance Derivatives With Respect to Turbocooler Flows}

PABAMETER

BASELINE WN25

SOURCE

SINK

DERIVATIVES:

$\triangle E$ EIPT

$\Delta \eta_{C C}{ }^{(P T S) / P T}$

$\% \Delta H P_{C C} / P T$

$\% \triangle W 41 R$ PT

$\Delta \eta_{S C}(\mathrm{PTS}) / \mathrm{PT}$

$\% \Delta \mathrm{HP}_{\mathrm{SC}}{ }^{\mathrm{PT}}$

OTHER

$\varepsilon_{H X}$

Thuel ( $\left.{ }^{\circ} \mathrm{F}\right)$

PS42 (PSI)

PT80 (PSI)

$\Delta \eta_{H P T}(\mathrm{PTS}) / \mathrm{PT}$
COOLED YANEJBURNER AIR

0.08

ATC COMPRESSOR

HPT NOZZLE, BURNER

$+0.400$

$+0.009$

$-0.026$

$-0.109$

$+0.027$

$+0.016$

0.900

1040

109.2

157.7

$-0.001$
COOLEDSTAGE IHPTROTORAIR ATC TURBINE DISCHARGEA

0.0252

0.021

ATC COMPRESSOR

HPT STAGE 1 ROTOR

ATC TURBINE

LPT NOZZREJUCT

$\because$

$+0.038$

$+0.037$

$-0.280$

$-0.255$

$-1.941$

$-1.555$

$-1.260$

$-1.249$

$-0.216$

$-0.246$

$-1.934$

$-1.655$

0.911

0.838

1052

975

106.8

107.0

157.7

261.7

$+0.081$

$+0.079$ 
TABLE 3.2.5

Reheat Burner Derivatives

\begin{tabular}{|c|c|}
\hline PARAMEIER & $\begin{array}{l}\text { RH BURNER } \\
\text { IEMPERATI }\end{array}$ \\
\hline BASELINE (NO REHEAT) & $\Delta \mathrm{T}=0$ \\
\hline \multicolumn{2}{|l|}{ DERIVATIVES: } \\
\hline$\Delta \Pi_{C C} / P T$ & $+0.005 / \% F$ \\
\hline$\% \Delta \mathrm{HP}_{\mathrm{CC}} / \mathrm{PT}$ & $+0.079 /{ }^{\circ} \mathrm{F}$ \\
\hline$\Delta \eta_{S C} / P T$ & $-0.007 /{ }^{\circ} \mathrm{F}$ \\
\hline$\% \Delta H P S C^{\prime P T}$ & $+0.055 /^{\circ} \mathrm{F}$ \\
\hline
\end{tabular}

\section{RHBURNER \\ PRESSURE RATIO}

$P / P=1.0$

$$
\begin{array}{r}
+0.096 \\
+0.165 \\
+0.200 \\
+0.446
\end{array}
$$

LPT ROTOR (4TH STAGE HPC COQLINGFLOW

$W N 25=0$

$-0.341$

$-1.196$

$-0.544$

$-1.826$ 


\subsection{COMBINED CYCLE STUDIES}

Using configuration 4, shown in Table 3.3.1, combined cycle studies were completed to determine combined cycle efficiency and power output. Two studies were completed with the following attributes:

\begin{tabular}{|c|c|c|}
\hline & Lower Heating Value-Natural Gas & Gas Turbine Exhaust Back Pressure \\
\hline Study 1 & $19,000 \mathrm{Btu} / \mathrm{bm}$. & 10 in. $\mathrm{H}_{2} \mathrm{O}$ \\
\hline Study 2 & $21,515 \mathrm{Btu} / \mathrm{bm}$. & 15 in. $\mathrm{H}_{2} \mathrm{O}$ \\
\hline
\end{tabular}

The combined cycle analysis were made using the following assumptions:

- A standard production Rankine steam bottoming cycle with three pressure levels and no reheat.

- One steam turbine per gas turbine.

- A condenser pressure of $1.2 \mathrm{in.} \mathrm{Hg}$.

- A generator loss of $1.2 \%$

The results of the combined cycle studies are shown in Figure 3.3.1 compared to the combined cycle goal of $59.2 \%$ and the program emission goals. The results show that the emission goal for NOx can be met, but there needs to be more cycle development to meet the combined cycle efficiency goal. 
TABLE 3.3.1

\section{ATS Engine Cycles Under Study}

ADVANCED TURBINE SYSTEMS(ATS) PROGRAM

ATS ENGINE CYCLES UNDER STUDY

\begin{tabular}{|c|c|c|c|c|c|c|c|}
\hline FEATURES & $1^{*}$ & $2^{*}$ & 3 & 4 & 5 & 6 & 7 \\
\hline $\begin{array}{l}\text { BOOSTER/DRIVE } \\
\text { TURBINE }\end{array}$ & NONE & $\begin{array}{l}\text { YES/LOW } \\
\text { PRESSURE } \\
\text { TURBINE } \\
\end{array}$ & $\begin{array}{l}\text { YES/LOW } \\
\text { PRESSURE } \\
\text { TURBINE } \\
\end{array}$ & $\begin{array}{l}\text { YES/LOW } \\
\text { PRESSURE } \\
\text { TURBINE } \\
\end{array}$ & $\begin{array}{l}\text { YES/LOW } \\
\text { PRESSURE } \\
\text { TURBINE }\end{array}$ & $\begin{array}{l}\text { YES/LOW } \\
\text { PRESSUE } \\
\text { TURBINE } \\
\end{array}$ & $\begin{array}{l}\text { YES/HIGH } \\
\text { PRESSURE } \\
\text { TURBINE } \\
\end{array}$ \\
\hline $\begin{array}{c}\text { BOOSTER DRIVE } \\
\text { TYPE } \\
\end{array}$ & NONE & $\begin{array}{l}\text { DIRECT } \\
\text { DRIVE }\end{array}$ & $\begin{array}{l}\text { DIRECT } \\
\text { DRIVE }\end{array}$ & $\begin{array}{l}\text { DIRECT } \\
\text { DRIVE } \\
\end{array}$ & $\begin{array}{l}\text { DIRECT } \\
\text { DRIVE }\end{array}$ & DIRECT DRIVE & $\begin{array}{l}\text { GEARED DRIVE } \\
\text { TO) } 3600 \text { RPM }\end{array}$ \\
\hline $\begin{array}{c}\text { PRESSURE RATIO } \\
\text { OF BOOSTER }\end{array}$ & 0 & 1.63 & 1.75 & 1.75 & 2.0 & 1.75 & 1.75 \\
\hline $\begin{array}{c}\text { ENGINE } \\
\text { AIRFLOW(LBS/SEC) }\end{array}$ & 223 & 317 & 352 & 352 & 372 & 352 & 352 \\
\hline $\begin{array}{l}\text { DRY LOW NOX } \\
\text { COMBUSTOR }\end{array}$ & YES & YES & YES & YES & YES & YES & YES \\
\hline TURBOCOOLER & NO & NO. & NO & YES & YES & YES & YES \\
\hline $\begin{array}{c}\text { NEW LOW } \\
\text { PRESSURE } \\
\text { TURBINE } \\
\end{array}$ & NO-GEYO & YES & YES & YES & YES & YES & YES \\
\hline $\begin{array}{l}\text { LOW PRESSURE } \\
\text { TURBINE SPEED }\end{array}$ & 2000 RPM & $3600 \mathrm{RPM}$ & $3600 \mathrm{RPM}$ & 3600 RPM & $3600 \mathrm{RPM}$ & $* * 2000 / 3600$ & $3600 \mathrm{RPM}$ \\
\hline $\begin{array}{c}\text { LOAD } \\
\text { CONNECTION } \\
\end{array}$ & GEARBOX & $\begin{array}{l}\text { DIRECT } \\
\text { DRIVE }\end{array}$ & $\begin{array}{l}\text { DIRECT } \\
\text { DRIVE }\end{array}$ & $\begin{array}{l}\text { DIRECT } \\
\text { DRIVE }\end{array}$ & $\begin{array}{l}\text { DIRECT } \\
\text { DRIVE }\end{array}$ & DIRECT DRIVE & DIRECT DRIVE \\
\hline $\begin{array}{l}\text { COMPRESSOR } \\
\text { DISCHARGE } \\
\text { TEMP. ( }{ }^{\circ} \text { F) } \\
\end{array}$ & 912 & 1075 & 1148 & 1148 & 1176 & 1148 & 1148 \\
\hline $\begin{array}{l}\text { TURBINE INLET } \\
\text { TEMP. (OF) }\end{array}$ & 2514 & 2500 & $\begin{array}{l}2500,2600 \\
2700,2800 \\
\end{array}$ & $\begin{array}{l}2500,2600 \\
2700,2800\end{array}$ & $\begin{array}{l}2500,2600 \\
2700,2800 \\
\end{array}$ & $\begin{array}{l}2500,2600 \\
27(0), 28(0) \\
\end{array}$ & $\begin{array}{l}2500,2600 \\
2700,2800\end{array}$ \\
\hline $\begin{array}{c}\text { POWER OUTPUT } \\
\text { MW }\end{array}$ & 43.95 & 59.6 & $\begin{array}{l}63.6,69.9 \\
76.4 .82 .9 \\
\end{array}$ & $\begin{array}{l}64.4,70.8 \\
77.3,83.4 \\
\end{array}$ & $\begin{array}{l}66.6,73.5 \\
80.4,87.4 \\
\end{array}$ & $\begin{array}{l}64.4 .70 .8 \\
77.3 .83 .4 \\
\end{array}$ & $\begin{array}{l}64.1 .70 .6 \\
77.0 .83 .4 \\
\end{array}$ \\
\hline $\begin{array}{l}\text { SIMPLE CYCLE } \\
\text { EFFICIENCY }(\%)\end{array}$ & 41.873 & 44.53 & $\begin{array}{l}45.11,45.7 \\
46.2,46.6\end{array}$ & $\begin{array}{l}45.5,46.1 \\
46.6,46.9 \\
\end{array}$ & $\begin{array}{l}46.0,46.2 \\
46.7,47.1 \\
\end{array}$ & $\begin{array}{l}45.5 .46 .1 \\
46.6 .46 .9 \\
\end{array}$ & $\begin{array}{l}45.31,45.98 \\
4(6.5 .46 .9 \\
\end{array}$ \\
\hline
\end{tabular}


ADVANCED TURBINE SYSTEMS(ATS) PROGRAM

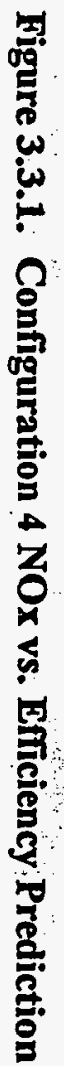

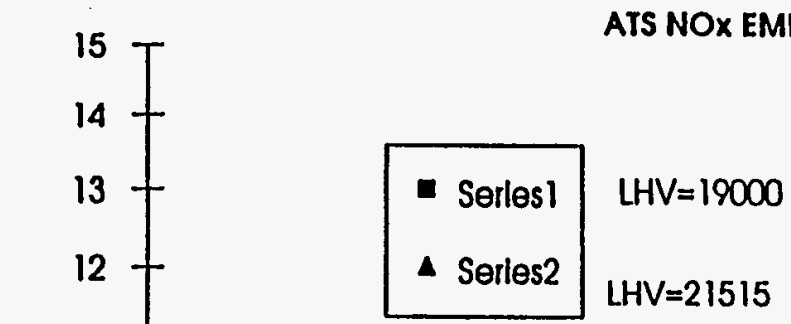

CONFIGURATION 4

(LMBOOO EFFICIENCY GOAL REFERENCE)

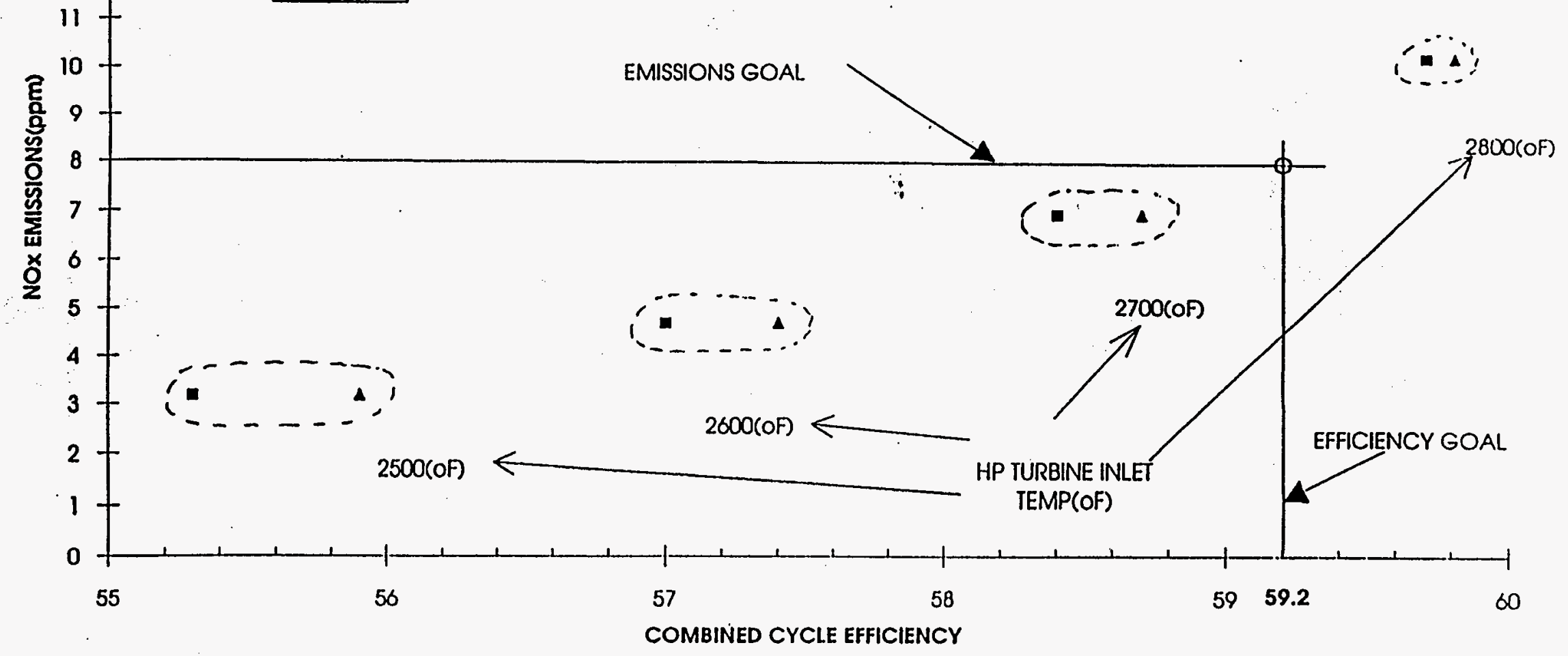




\subsection{COMBUSTOR AERO DESIGN}

The combustor preliminary aero design effort during this reporting period focused in part on continued generation of flowpath layouts that accommodate the challenging performance requirements of the combustion system, yet fit into the available GE90 CDN with a minimum of mechanical modifications. In addition some supporting 3D CFD and chemical kinetics analysis were performed to get a first-cut look at the performance.

The current status of the preliminary aero layout has a combustion system, (compressor OGV trailing edge to turbine nozzle leading edge), flowpath that is approximately 1.85 inches longer than the current GE90. Figure 3.4.1 provides an illustration of the current combustor flowpath aero layout. The combustor preliminary design features a tri-dome configuration, in which there are 60 equally spaced mixer/injector assemblies in the outer two domes and 30 equally spaced mixer/injector assemblies in the inner dome. The lesser number in the inner dome is the result of circuimferential spacing constraints. This is double the number of mixer/injector assemblies as featured in the LM6000 DLE combustor. This was done to allow for smaller mixer/injector assemblies, which reduced their length to better fit the overall combustion system into the limited available space of the GE90 CDN. The mixer/injector assemblies were designed using the DCARS mixer design criteria developed for the LM6000 DLE combustor. Analysis show that residence times in the mixer/injector assemblies are on the order of 0.6 to $0.8 \mathrm{msec}$. This should be low enough to prevent autoignition at all operating conditions. A similar mixer/injector dome configuration as used in the current LM6000 DLE is adopted. A tri-passage combustor inlet diffuser is also featured. This design provides for reduced length for a given area ratio and performance, and allows for better alignment of the compressor discharge flow streams into each of the three combustor domes to improve recovery and flow feed into the mixers.

A fully 3D CFD analysis of the current combustor design was performed using the CONCERT code developed at GE. CONCERT is a state-of-the-art 2D/axisymmetric or fully 3D elliptic turbulent flow code with fuel addition and combustion capability. CONCERT was developed expressly for application to gas turbine engine combustion systems and has been in production use at GE since 1987. CONCERT has been used for providing predictions of combustor exit gas temperature performance, and exhaust emissions including $\mathrm{CO}, \mathrm{UHC}$, and NOx. CO and UHC predictions are provided via a simple 2-step reaction/eddy breakup type model, while NOx predictions are provided by a Zeldovich mechanism. The predictions of these emissions species are not highly accurate for very lean combustor designs do to the limited chemical kinetics that can be practically used with a fully $3 \mathrm{D}$ calculation. CONCERT undergoes continual enhancement to improve predictive accuracy and applicability. For a typical 3D analysis, a single periodic section of the combustor is modeled. This assumption allows sufficient grid detail within limited available computer resources. This approach in essence assumes that all periodic sections of the combustor are identical. A grid network of $85 \times 69 \times 33(193,545)$ grid points was used for this model. Figure 3.4.2 presents views of the model grid for the three principal planes. Figure 3.4.3 shows the flow splits used for the model. Boundary conditions defining the mixer/injector discharge flow characteristics into the combustor were obtained from a CONCERT axisymmetric flow analysis of the mixer/injector. A single case was run representing maximum power operating conditions. The results, (using gaseous methane fuel), are presented in Figures 3.4.4 and 3.4.5, showing as expected with essentially no cooling flow the exit profile is essentially flat. Predictions of $\mathrm{CO}$ and 
UHC emissions at the max. power operating condition, made as part of this modeling analysis, show a CO level of $3.5 \mathrm{ppm}$ and the UHC level at $1.3 \mathrm{ppm}$.

Predictions of emissions were also made utilizing the CELESTE code. CELESTE is a stirred reactor type model developed at GE. It allows for the constructing of a network of perfectly stirred and/or plug flow reactors to represent the combustor. Because there are no complex fluid mechanics involved, more detailed chemical kinetics can be used than possible with the fully $3 D$ CFD type analysis. In the analysis performed a kinetics mechanism consisting of 154 reactions was used. CELESTE models for the max. power and $40 \%$ power operating condition were run. Figure 3.4.6 shows the simplistic network of reactors used. A natural gas representative fuel was used in these analyses. For the max. power condition the predicted emissions levels were $5.7 \mathrm{ppm}(\mathrm{CO})$ and $10 \mathrm{ppm}$ (NOx). Given the predictive uncertainty of this model, the predicted NOx levels are consistent with the goals for the combustor. Results with this same model at the $40 \%$ power operating condition failed to produce a combusted solution. The fuel/air mixture was below the lean extinction limit. This is in agreement with test results of the DCARS mixer/injector assembly supporting the LM6000 DLE development. This outcome suggests the need to stage the combustor to maintain stability at this operating condition. A second CELESTE model was built to represent staging the combustor, the inner dome unfueled while the outer and center domes were fueled. With staging the two fueled domes operate at a fuelair mixture above the lean extinction limit. Flow splits for this configuration and the CELESTE model of networked reactors is shown in Figure 3.4.7. The predicted results from this revised model at the $40 \%$ power operating condition were $20 \mathrm{ppm}$ for (C)] emissions and $3 \mathrm{ppm}$ for (NOx) emissions. 


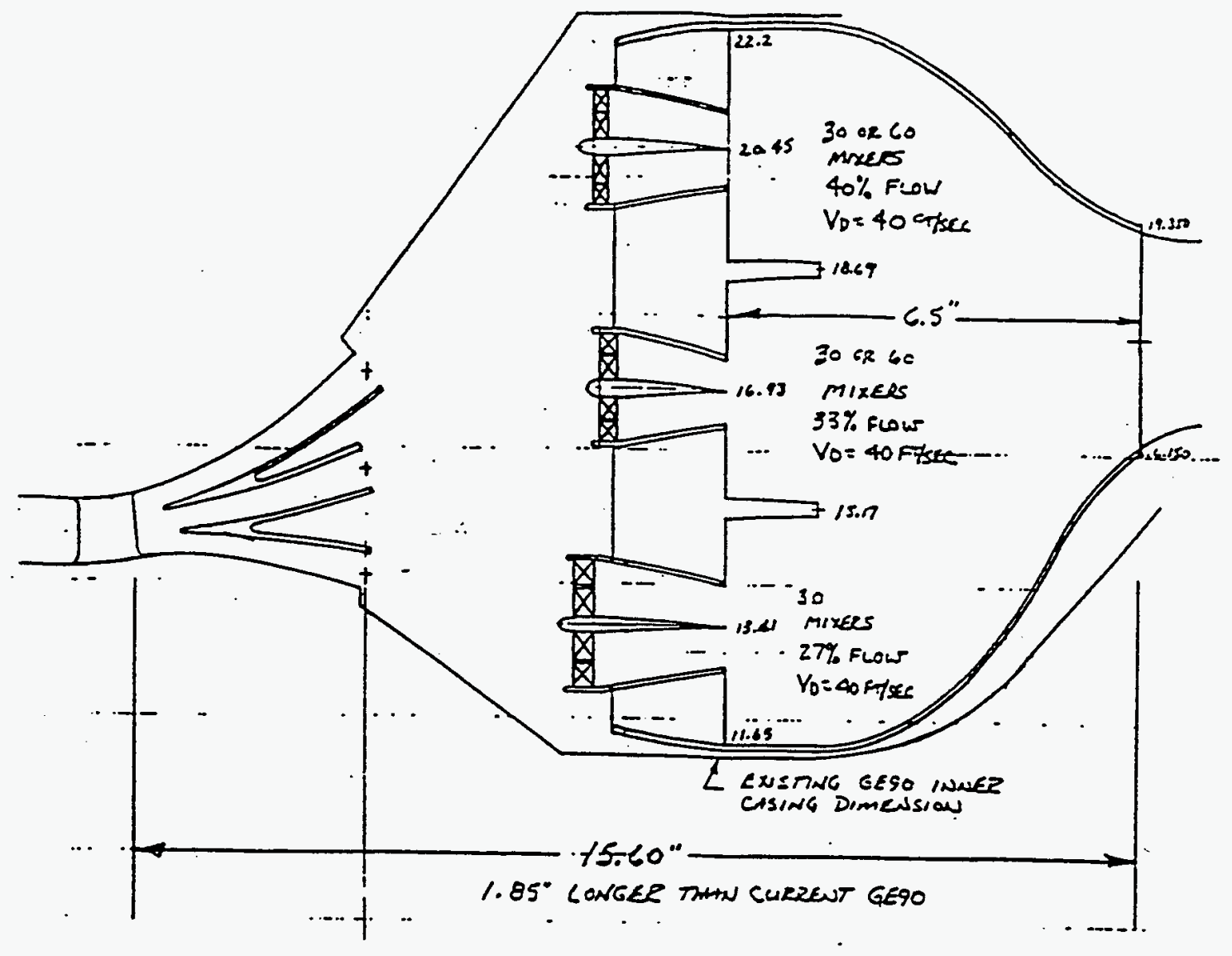

Figure 3.4.1. Current Combustor Preliminary Aero Layout 


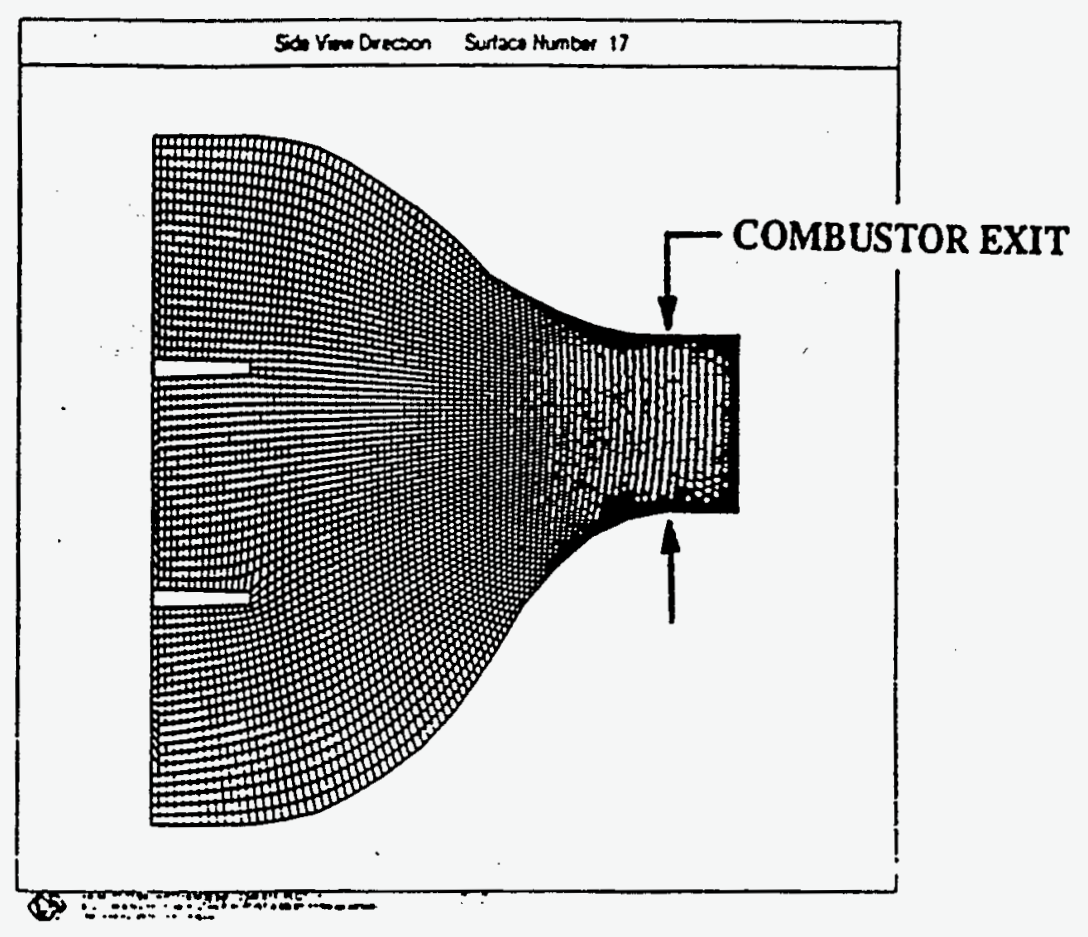

SIDE VIEW PLANE

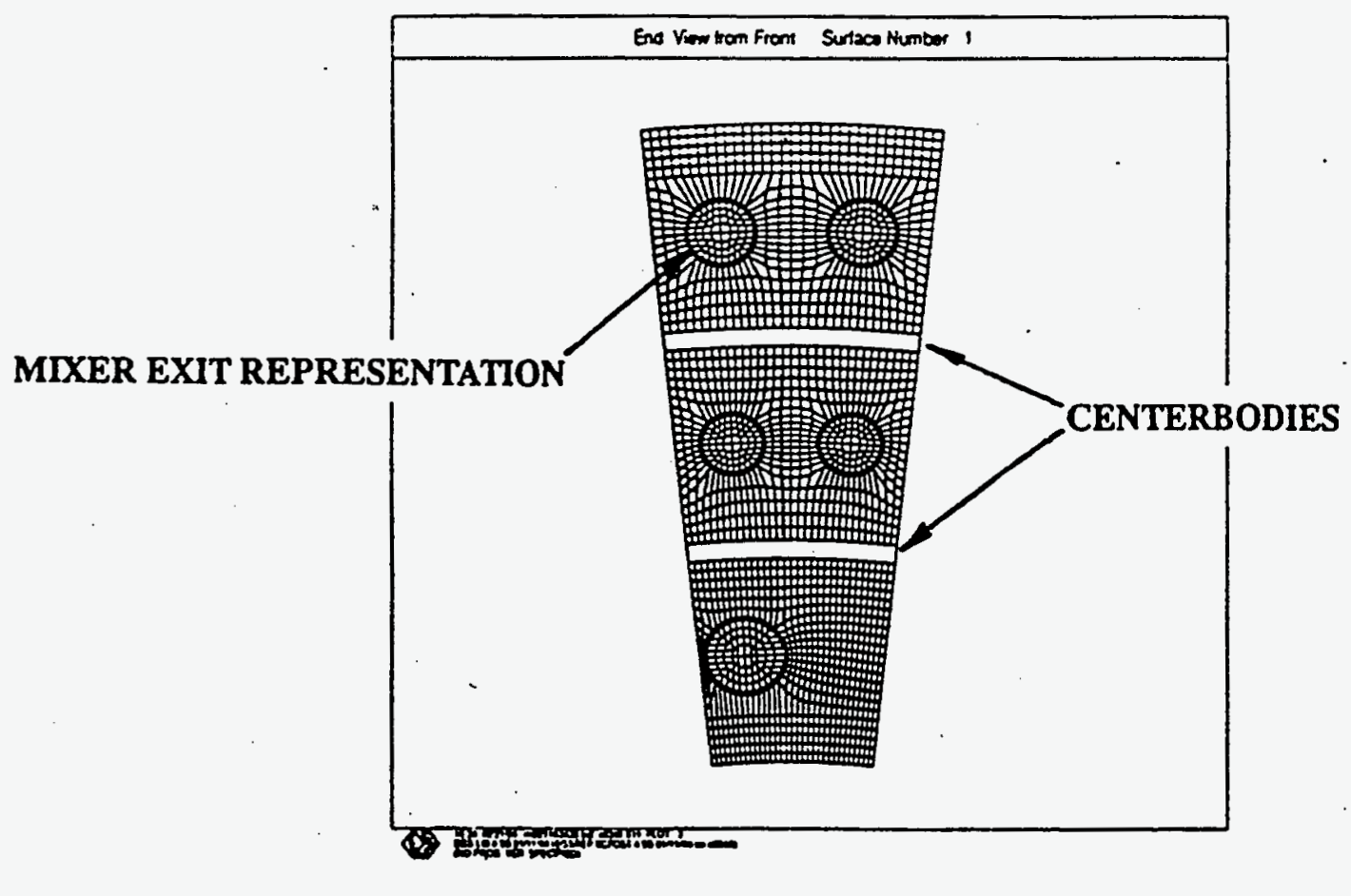

END VIEW OF MODEL INLET PLANE

Figure 3.4.2. Combustor Grid Model 


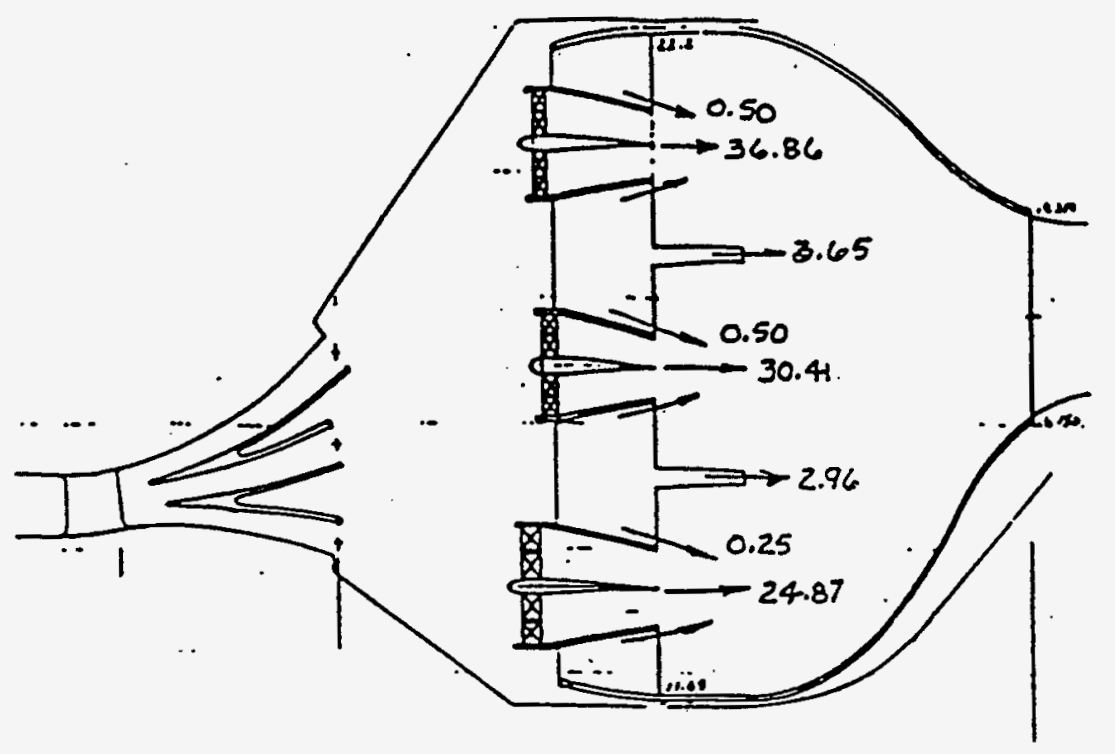

COMBUSTOR MODEL FLOW DISTRIBUTION (\% Wombustor)
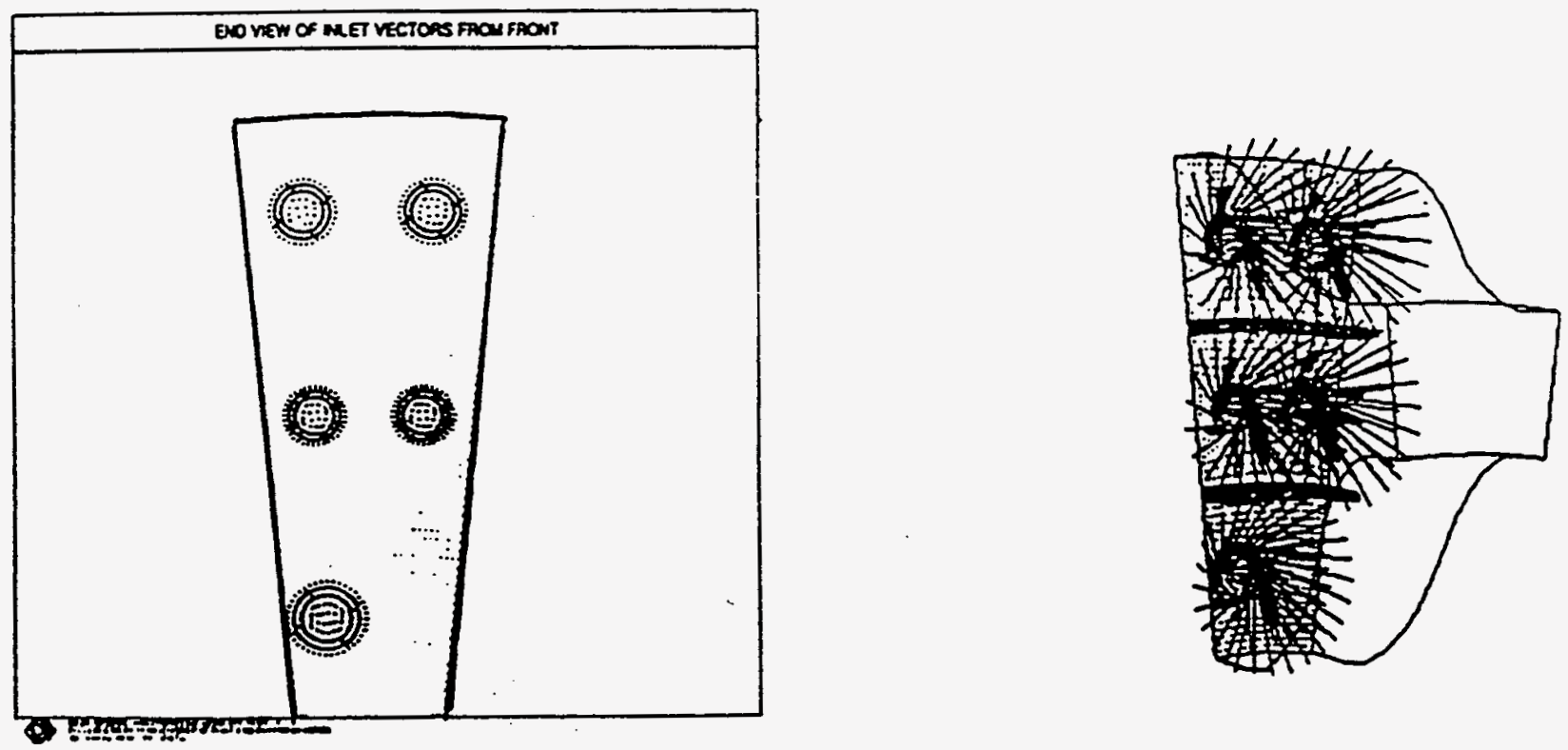

MODEL INLET VELOCITY BOUNDARY CONDITIONS

Figure 3.4.3. CONCERT3D Model Flow/Boundary Conditions 

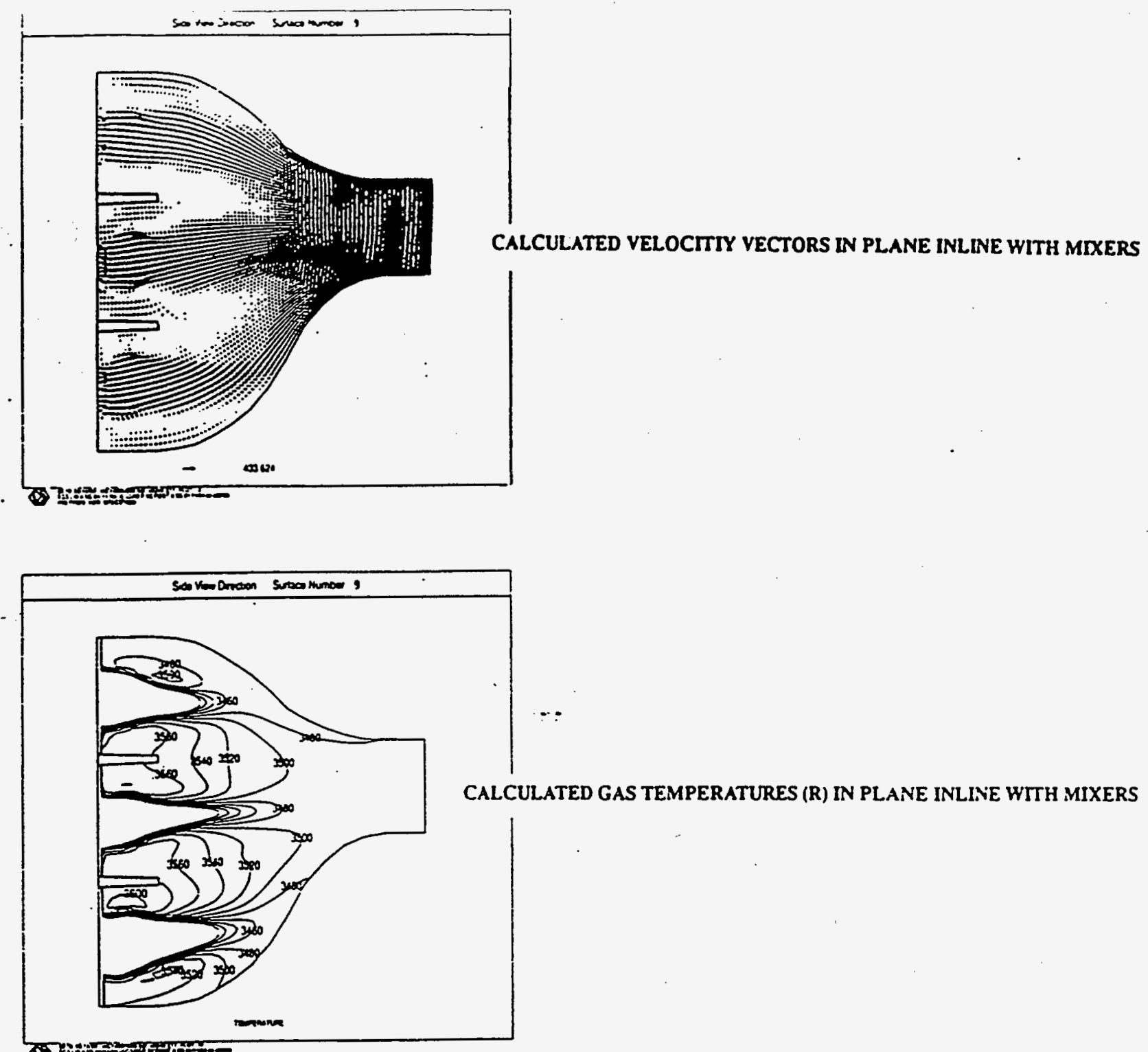

670

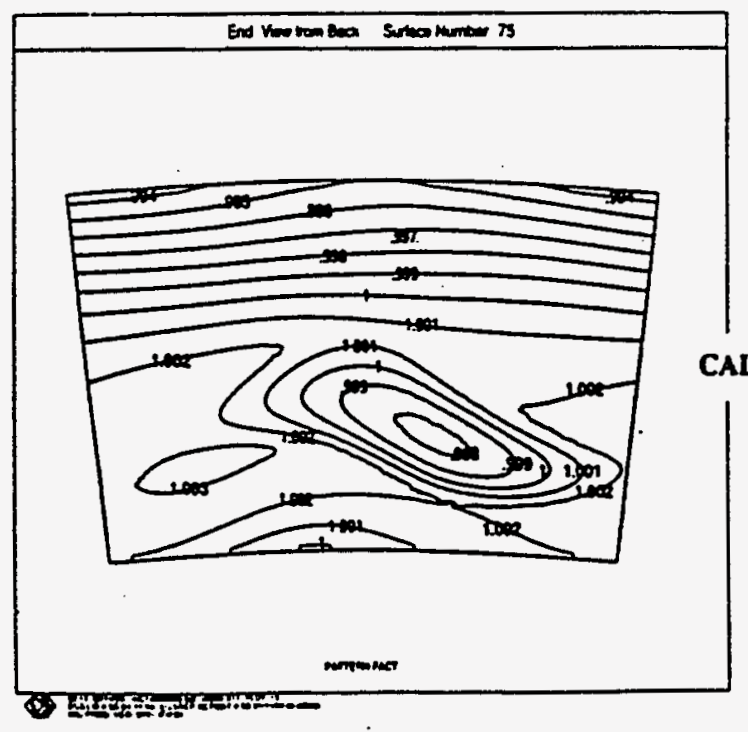

Figure 3.4.4. Combustor Flow Model Results 

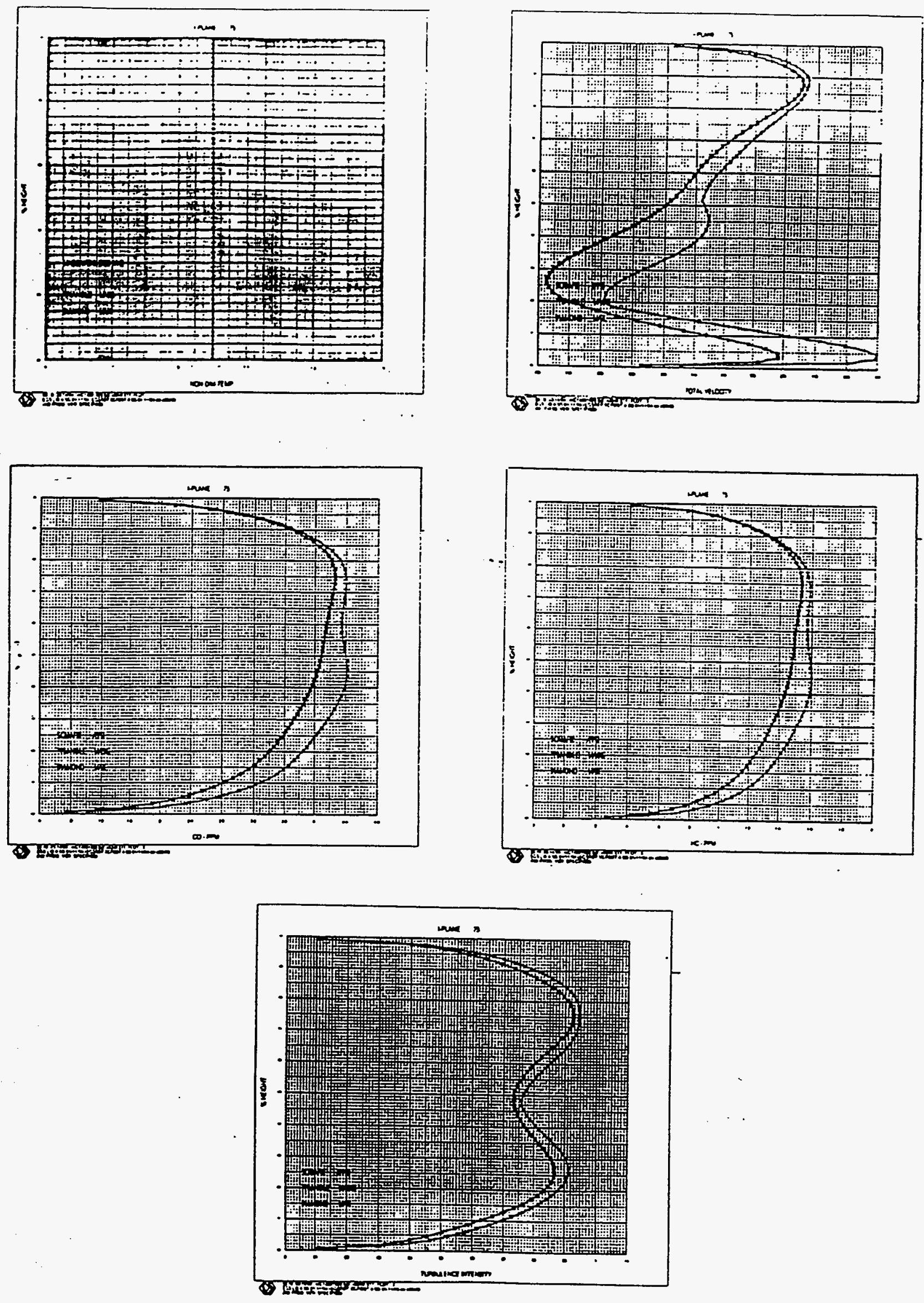

Figure 3.4.5. Calculated Circumferentially Averaged Exit Profiles 


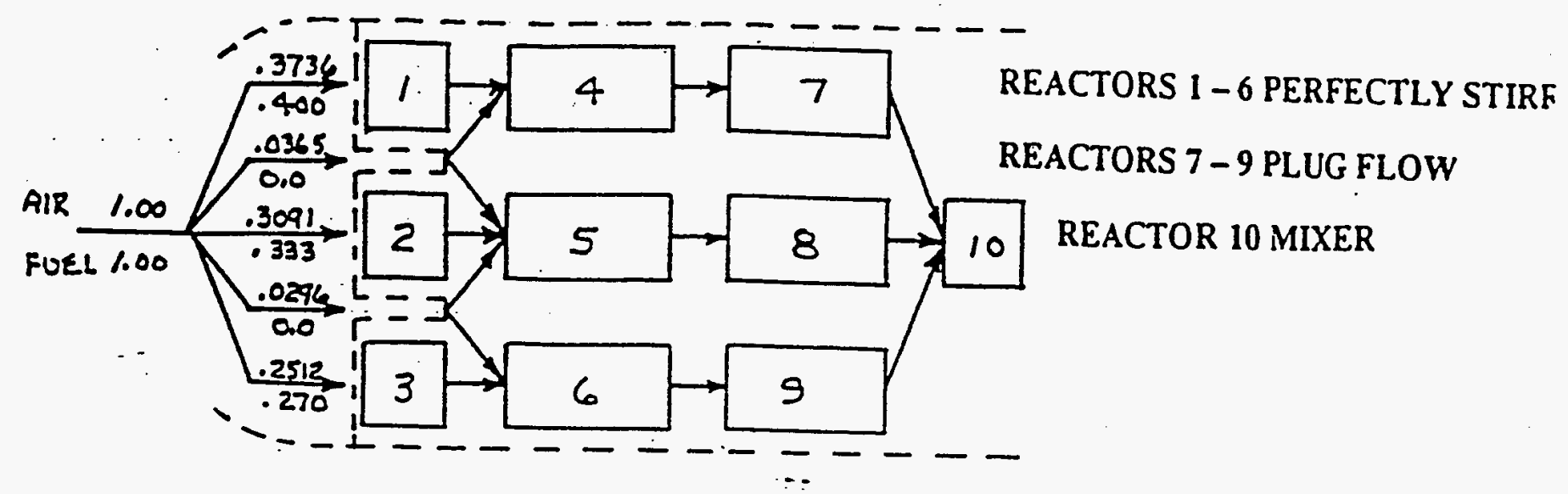

Figure 3.4.6. CELESTE Stirred Reactor Model for Max Power

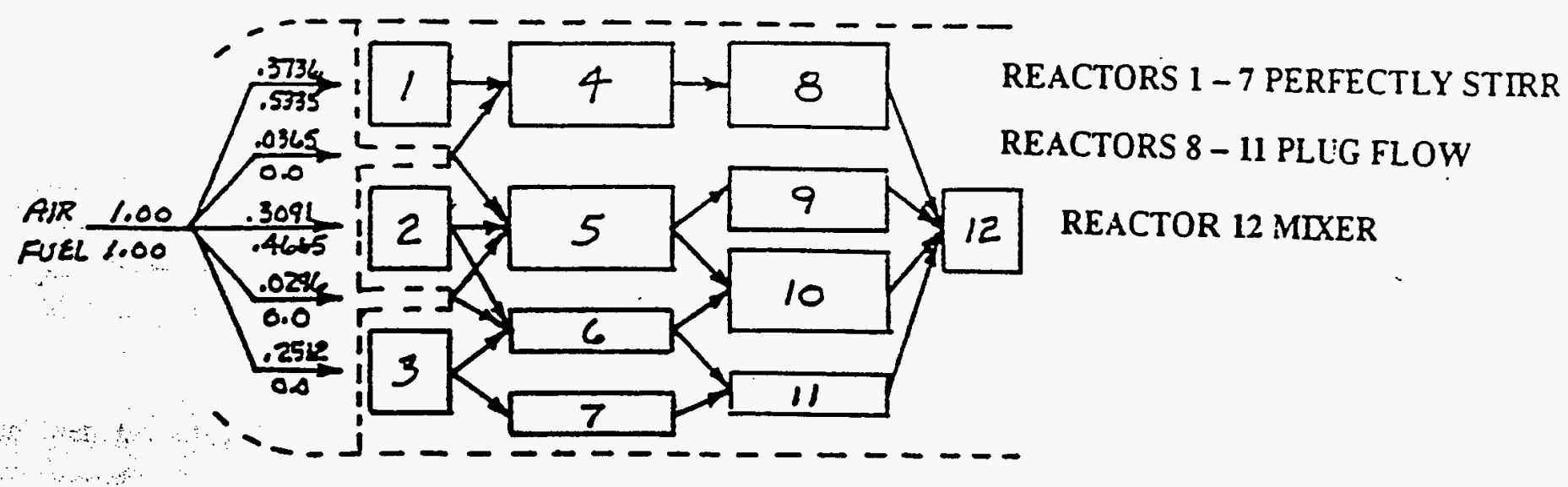

Figure 3.4.7. CELESTE Stirred Reactor Model for $40 \%$ Power 


\subsection{HIGH PRESSURE TURBINE HEAT TRANSFER}

Preliminary turbine cooling designs for the high pressure turbine vane and blade were developed in the previous reporting period to support the evolution of the ATS cycle and establish the design constraints necessary for a successful detailed design. In this reporting period, technical challenges were addressed pertaining to the thermal barrier coating on the HPT Stage 1 vane and cooling flow estimates were made for the HPT Stage 2 vane.

The ATS turbocooler provides cooling flow to the combustor liners and high pressure turbine airfoils and bands at reduced temperatures and increased pressures as compared to traditional CDP air cooled designs. Flow from the turbocooler cools the combustor outer liner, vane outer band, and HPT shroud individually. It also cools the HPT vane and the spent cooling air from there is used to cool the combustor inner liner, vane inner band, HPT Stage 1 blade, and forward combustor seal. A preliminary estimate of the cooling flow breakdown is as follows:

\begin{tabular}{|c|c|}
\hline & Wc $(\% \mathrm{~W} 25)$ \\
\hline Combustor Inner Liner & $1.5^{*}$ \\
\hline Combustor Outer Liner & 1.5 \\
\hline HPT Vane Inner Band \& Leakage & $1.0^{*}$ \\
\hline HPT Vane Outer Band \& Leakage & 1.5 \\
\hline HPT Vane Film & $3.7^{*}$ \\
\hline HPT Shroud & 0.5 \\
\hline HPT Stage 1 Blade & $2.2^{*}$ \\
\hline Forward Combustor & $\underline{0.4^{*}}$ \\
\hline Total & 12.3 \\
\hline
\end{tabular}

Note: All flows noted with a ${ }^{*}$ pass through the HPT vane: $3.67 \% \mathrm{~W} 25$ is film and $5.1 \% \mathrm{~W} 25$ is non-film which is captured and used to cool the combustor inner liner, vane inner band, HPT Stage 1 blade, and forward combustor seal.

\section{HPT Stage 1 Vane}

Cooling flow for the high-pressure turbine vane is supplied from the turbocooler at much lower temperatures and higher pressures than the conventional vane coolant supply from CDP air. The HPT vane cooling design, as proposed in the previous reporting period, used only trailing edge film in order to minimize the cooling flow and film requirements to achieve life. The cooling circuit included two impingement inserts for increased heat transfer, but, rather than exhausting through film holes as in traditional designs, the post impingement flow is captured at the hub of the airfoil and used to cool the combustor inner liner and HPT blade. The ability to reuse the spent vane cooling air is only possible due to the increased pressures and lower cooling temperatures supplied by the Turbocooler. Typical impingement/film cooled vane designs are limited by backflow margins (Pcoolant/Pgas) at the leading edge of the vane to prevent gas ingestion. This is not a restriction for the ATS design; only the cooling air pressure supplying the combustor inner liner, which is the vane cooling air exhaust pressure, is a design constraint. 
The TBC surface temperatures proposed for the ATS vane were much higher than our previous experience on either aircraft or military and industrial applications. There was a concern that the TBC would sinter and that the TBC thermal conductivity would increase at these temperatures. Therefore, based upon the recommendations of our material technologists, TBC outer surface temperatures were limited to $2350 \mathrm{~F}$, and TBC bond coat interface temperatures were limited to $1920 \mathrm{~F}$. These design constraints dictated that the vane design should be modified to include additional film cooling. Only 10 mils of TBC are required to achieve these temperature limits, however, which also reduces the technical challenge of thicker TBC. Five mils of TBC are not atypical on today's airfoils, although up to ten mils have been tested for limited periods.

A listing of the ATS vane parameters is as follows:

$\begin{array}{lr} & \text { ATS } \\ \text { Hot Streak Temperature (F)) } & 3075 \\ \text { Coolant Temperature (F) } & 719 \\ \text { Pcoolant/Pgas } & 1.10 \\ \text { TBC Thickness (mils) } & 10 \\ \text { Wc (\%W25) } & 8.77 \\ \text { Film (\%W25) } & 3.67 \\ \quad \text { NonFilm (\%W25) } & 5.10 \\ \text { Life (cycles) } & 10,000\end{array}$

The non-film cooling flow which cools the ATS vane impinges on the airfoil and goes on to cool the combustor inner liner and HPT blade; of the remaining film flow. $1.12 \%$ W25 film flow exhausts through the trailing edge slots and $2.55 \% \mathrm{~W} 25$ is used as pressure and suction side film. Figure 10 indicates the ATS film geometry and flow distribution. Preliminary metal and TBC temperatures are shown in Figure 11. Additional concepts are still under consideration for further iterations on the cooling design of the vane.

\section{HPT Stage 2 Vane}

The coolant supply for the ATS HPT Stage 2 Vane is supplied from the exhaust from the Turbocooler turbine. Cooling air is furnished at temperature and pressure levels similar to the GE90 design conditions which is fed with 7th stage bleed as shown below.

$\begin{array}{lr}\text { P3 Design Point } & \text { ATS } \\ \text { Ps Vane 2 Source } & 588.2 \\ \text { Gas Temperature (F) } & 299.1 \\ \text { Coolant Temperature (F) } & 2488 \\ \text { TBC Thickness (mils) } & 948 \\ \text { Wc (\%W25) } & 4 / 7 / 10 \\ \text { Forward } & 2.50 \\ \quad \text { Aft } & 1.13 \\ \text { Trailing Edge } & 0.15 \\ \text { Life (cycles) } & 1.22 \\ & 10,000\end{array}$


The life limiting location of the ATS HPT Stage 2 vane is the trailing edge. In order to achieve the ATS life requirements, the trailing edge temperatures will have to be reduced -100F below GE90 temperatures. This can be accomplished with increased pressure side film and trailing edge flow. A listing of the ATS flows are shown in Figure 3.5.3. Figure 3.5.4 indicates the TBC distribution and the life-limiting temperatures for the ATS.

\section{Technology/Testing Needs}

\section{Vane Impingement with Crossflow Test:}

The HPT vane cooling design relies upon impingement air providing enhanced coolant side heat transfer coefficients. Rather than film cooling the airfoil, the flow is captured at the hub of the airfoil and reused as combustor liner or HPT blade cooling. Intercepting the flow implies that some of the benefit of higher impingement heat transfer coefficients will be reduced due to cross-flow. The vane design will be dependent upon optimization of the internal cooling concept.

Three configurations have been tested for vane impingement with crossflow - a baseline and two variations.

\section{Technology Challenges}

TBC provides a technical challenge in many arenas: spallation of the TBC is not fully known; temperatures through the TBC as well as the maximum temperature of the TBC are areas of concern for the ATS life requirements. 


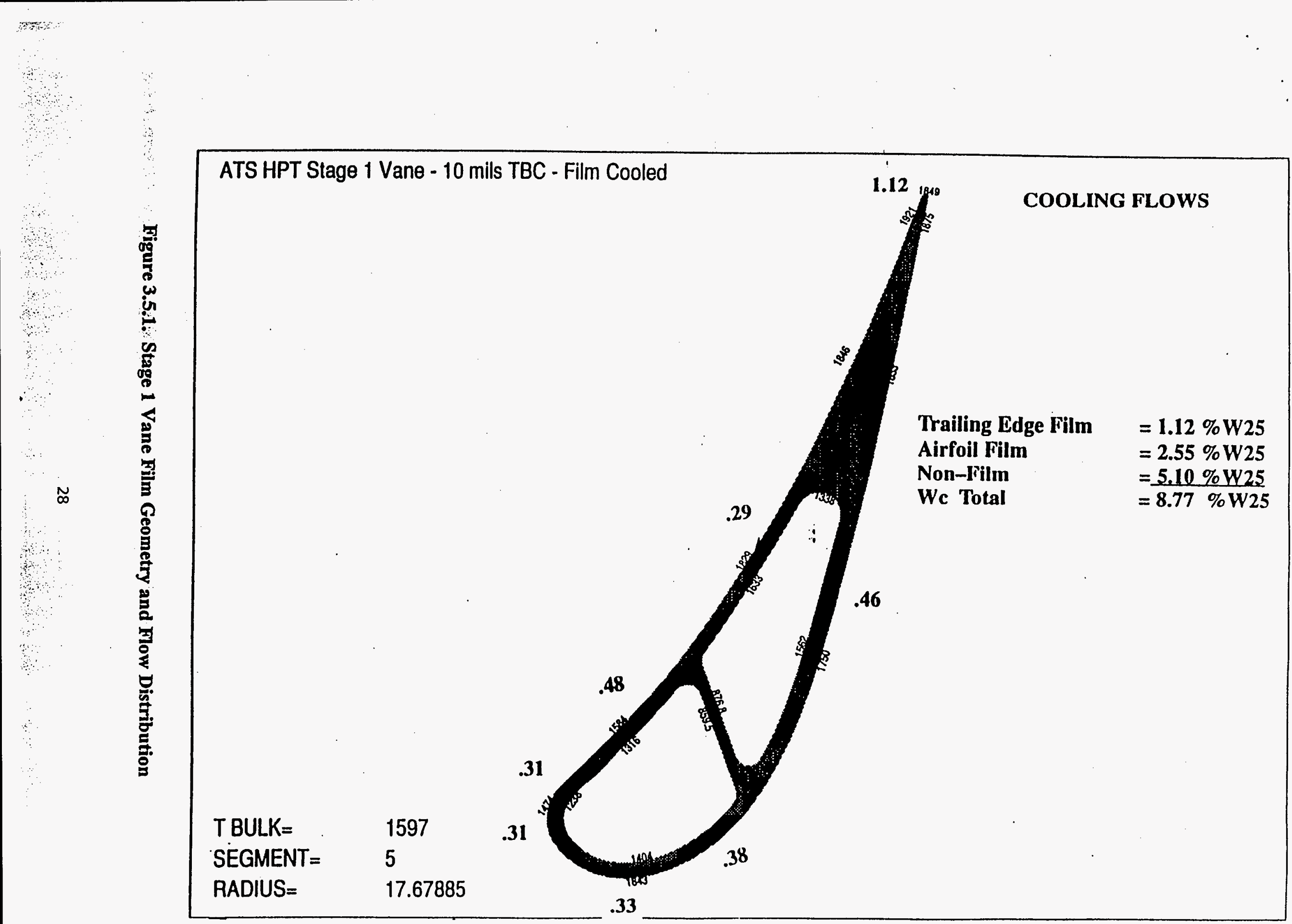




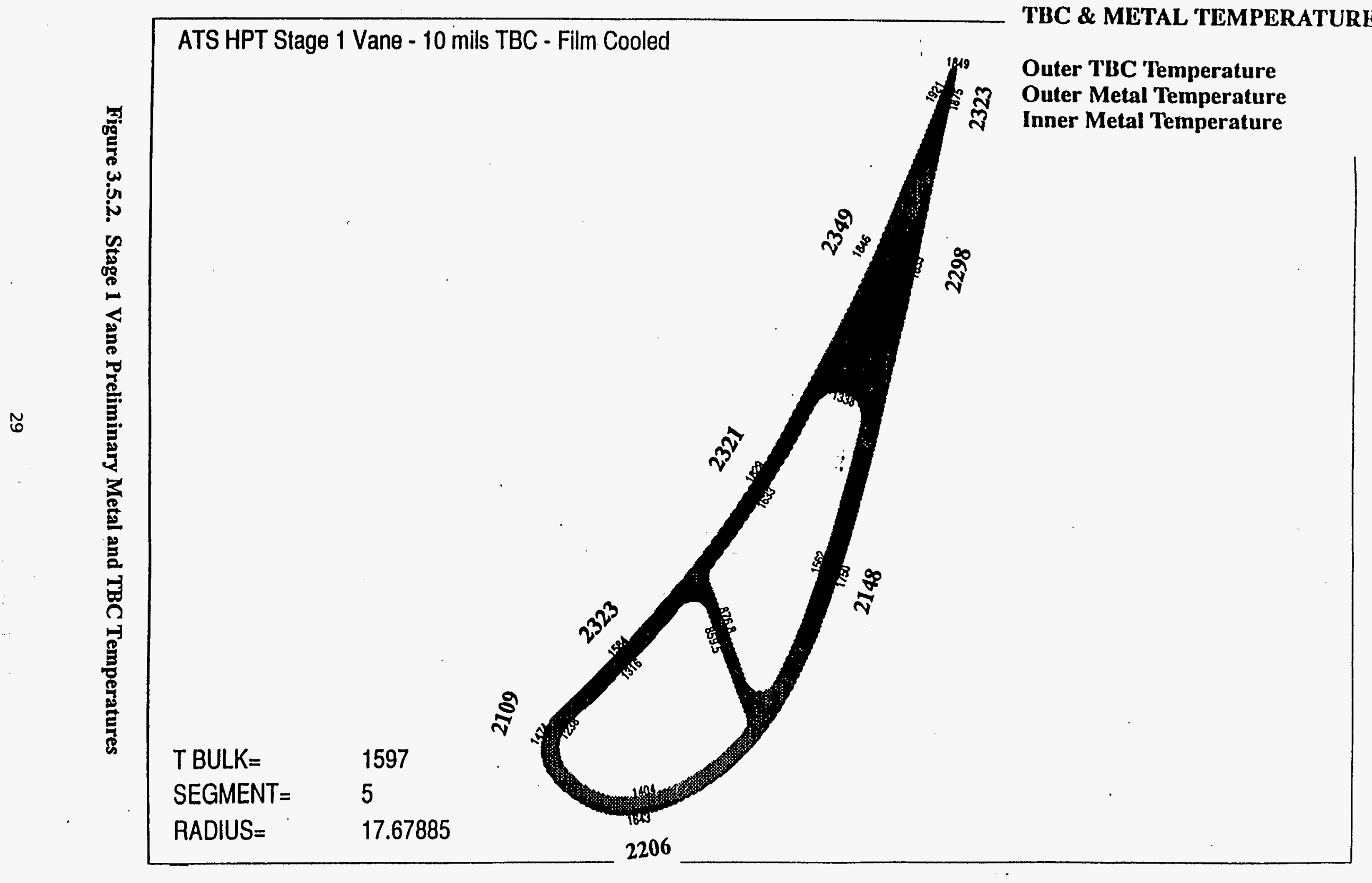




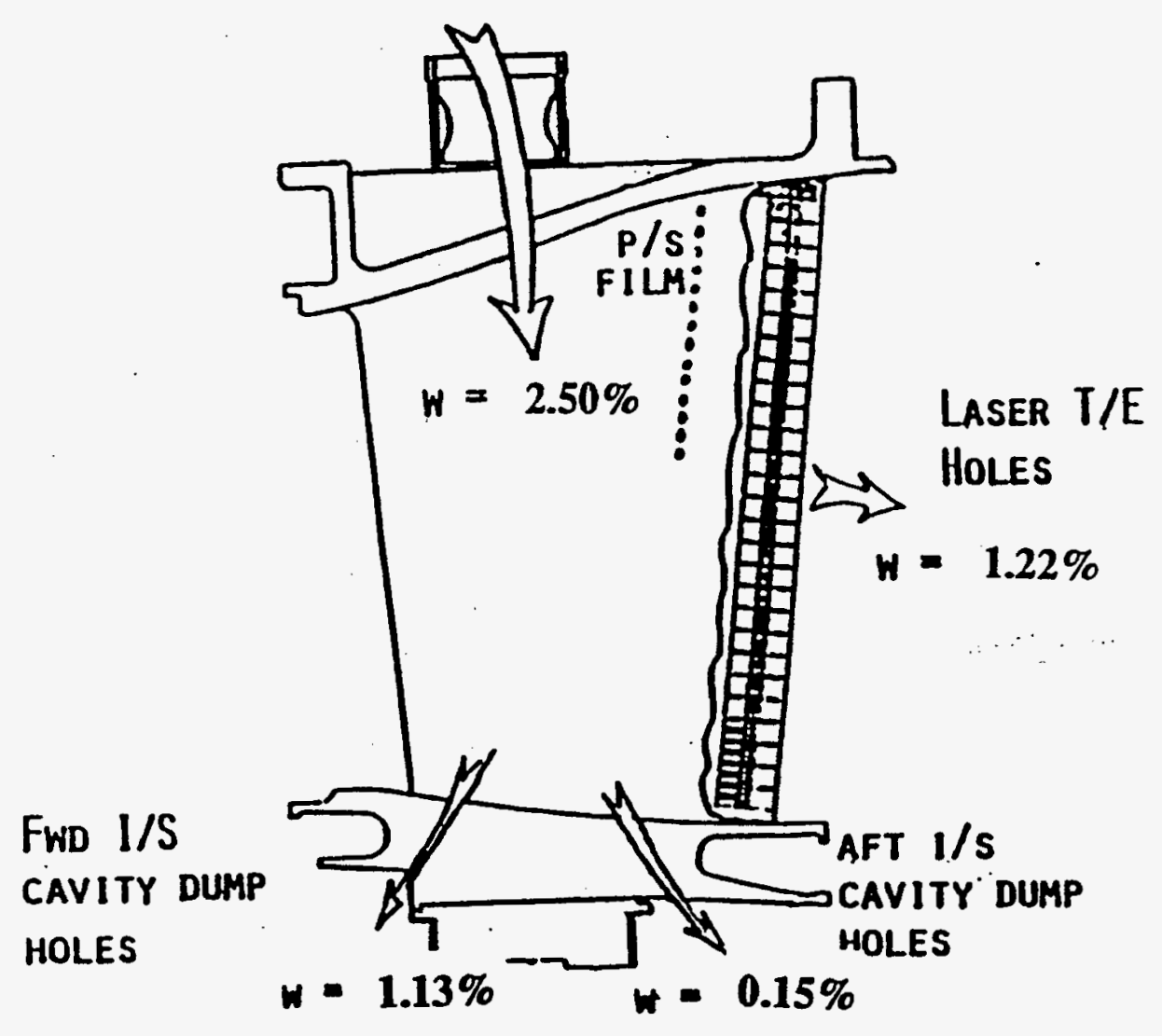

Figure 3.5.3. ATS Stage 2 Vane Cooling Flows 
TBC Thickness Distribution

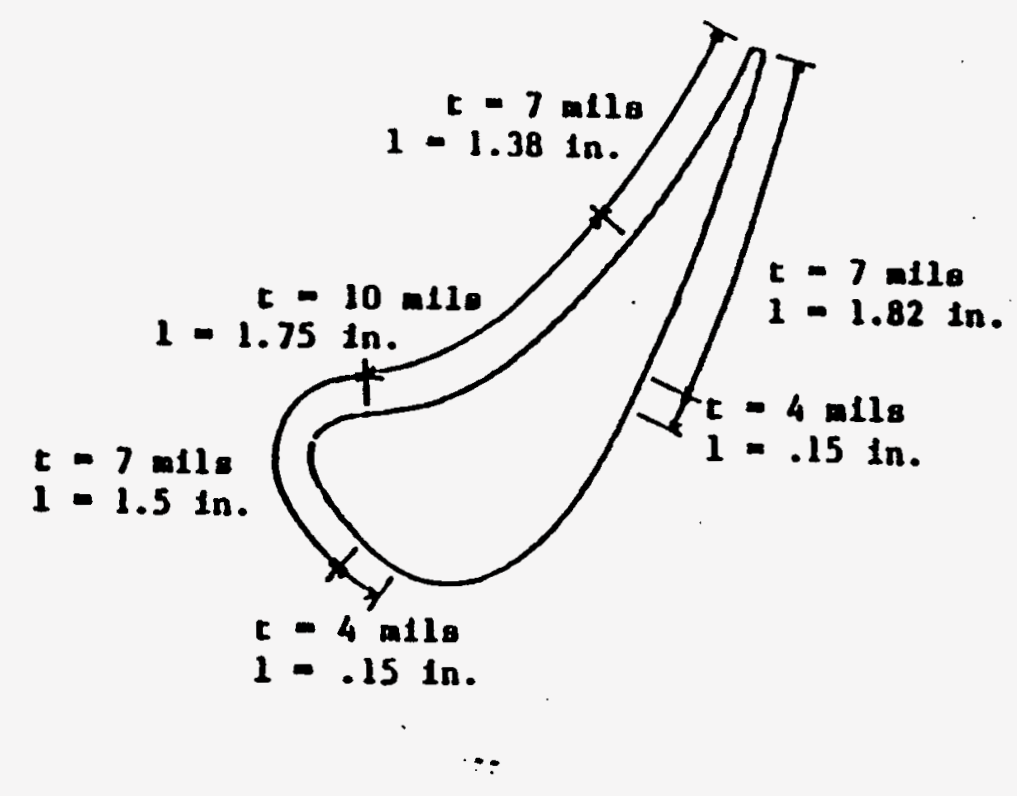

\section{Tmax = 1929F @ airfoil trailing edge 10000 cycles}

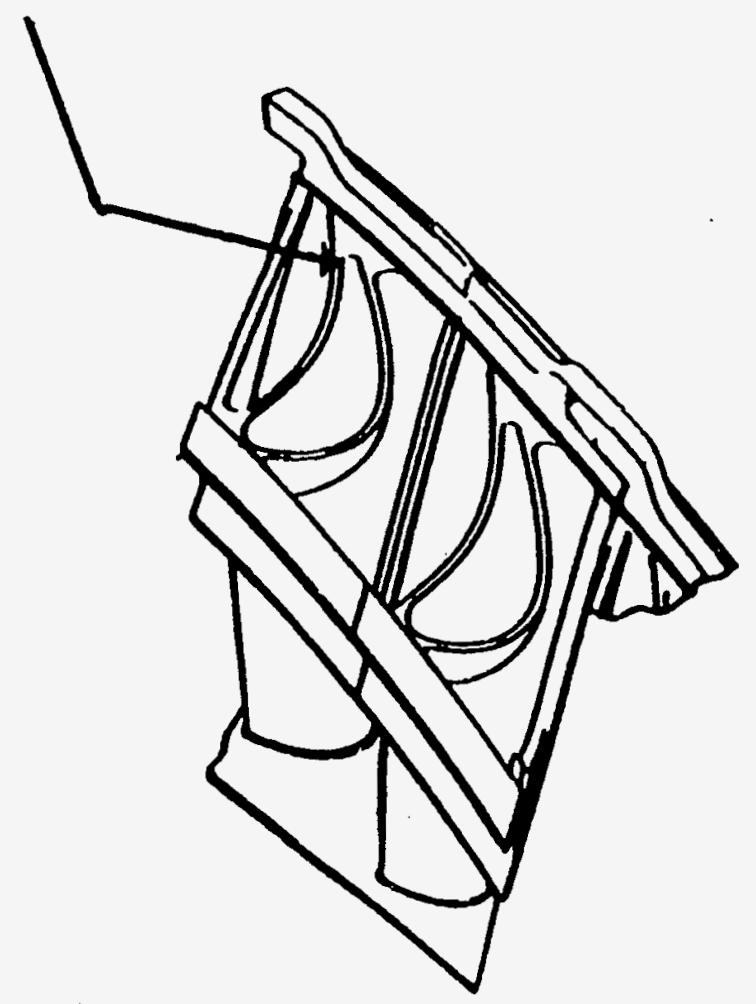

Figure 3.5.4. Stage 2 Vane TBC Distribution and Life-Limiting Temperatures 


\subsection{TURBOCOOLER SYSTEM}

An internal preliminary design of the turbocooler (Turbocooler) system has been completed, using as a base the Allied Signal compressor and turbine maps provided for another application.

The current size accommodates an increased primary cooling flow requirement of $12.35 \% \mathrm{~W} 25$, up from the $10.52 \%$ Proposal value, due to TBC temperature limits.

A preliminary layout of the system was used to estimate the system pressure losses is shown in Figure 3.6.1. Pressure distribution in the system at full power is shown in Figure 3.6.2.

Current pressure drops are higher than Proposal values for both the turbocooler turbine and turbocooler compressor circuits. Effects of the pressure drop estimates on the system include an increase in the required turbocooler compressor pressure ratio from 1.2 to 1.29 , and an attendant increase in the fuel sink utilization to maintain turbocooler primary coolant supply temperature of 700F. The available air side pressure drop in the heat exchanger was reduced to partially compensate the increased extraction and feed losses.

In the current design, the turbocooler turbine exhaust is directed to and provides cooling for the engine HPT second-stage vane, replacing the HPC (high-pressure compressor) interstage coolant for this purpose. The resultant increase in turbocooler turbine exit pressure (relative to the proposed system) reduces the available head, requiring an increase in extraction for the purpose of driving the turbocooler compressor. There is more air available for downstream (secondary) cooling, but it will necessarily be hotter than the HPC interstage source. The increased primary flow and pressure requirements, noted above, and the increase in pressure loss in the turbocooler turbine circuit also contribute to an increase in turbocooler turbine extraction levels.

Meeting the primary cooling requirements (HPT vane and blade, burner liner and HPC shaft) at the baseline required-to-run fuel flow results in a fuel temperature at the burner of 1049F. (Column $\mathrm{A}$ below). Fuel temperature at the burner can be maintained at $1000 \mathrm{~F}$ only by reducing the primary coolant $0.75 \%$ W 25 (B), or increasing its supply temperature by $36 \mathrm{~F}$. Column D provides a comparison with the original proposal system.

Primary coolant (\%W25)

Supply temperature (F) @ HPT Stage 1 vane

Fuel temperature at burner (F)

$\mathrm{HX}$ volume $\left(\mathrm{ft}^{3}\right)$

Turbocooler wheel diameter (in.)

Turbine exit temperature (F)

Turbocooler wheel diameter (in.)

Turbocompressor speed (rpm)

Turbocooler pressure ratio

Turbocooler pressure ratio

$\begin{array}{cccc}\underline{\mathbf{A}} & \underline{\mathbf{B}} & \underline{\mathbf{C}} & \underline{\mathbf{D}} \\ 12.35 & 11.60 & 12.35 & 10.5 \\ 700 & 700 & 736 & 700 \\ 1049 & 1001 & 1000 & 893 \\ 1.78 & 1.4 & 1.32 & 0.8 \\ 6.18 & 6 . & 6.23 & 6.34 \\ 1003 & 1003 & 1003 & 735 \\ 5.3 & 5.1 & 5.25 & 11.1 \\ 46,840 & 48,590 & 47,220 & 37,650 \\ 1.29 & 1.29 & 1.29 & 1.19 \\ 1.58 & 1.58 & 1.58 & 4.35\end{array}$




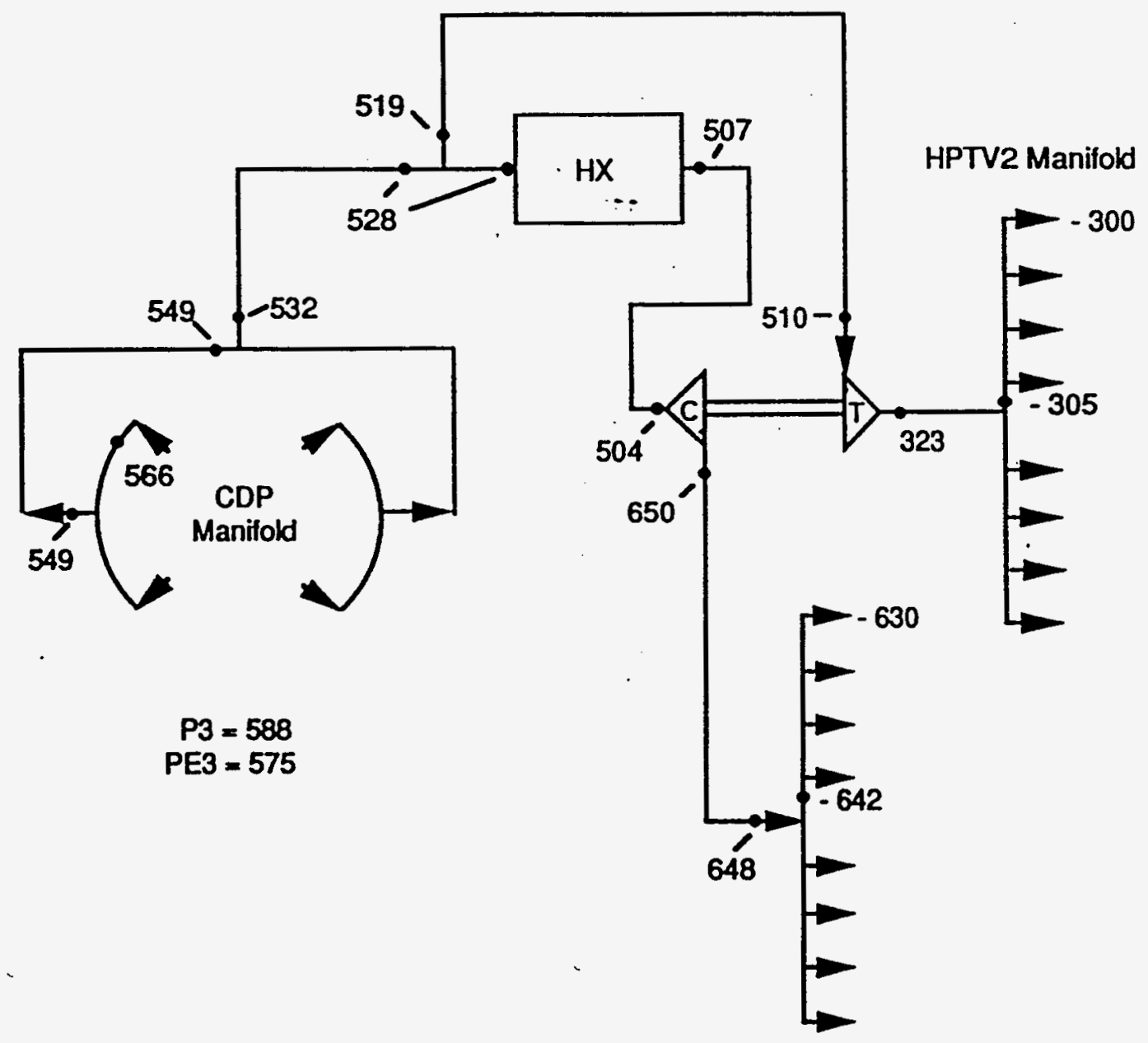

Figure 3.6.1. Estimated Pressure Distribution in ATS Turbocooler at Full Power 


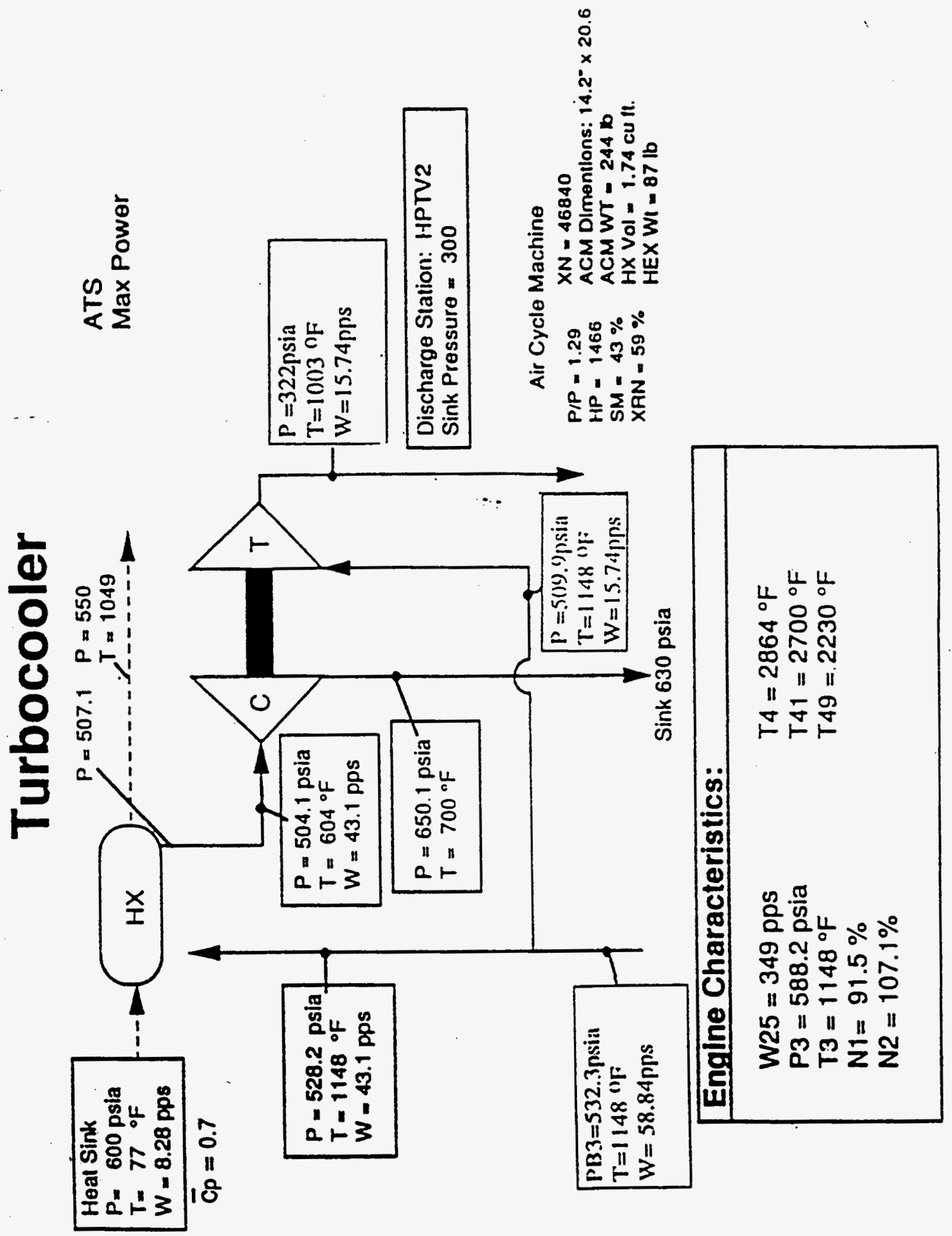

Figure 3.6.2. Turbocooler Pressure Distribution 


\subsection{LOW PRESSURE TURBINE DESIGN}

\section{Mechanical Design}

The ATS power turbine is a five-stage design that drives both the low-pressure booster and the power output shaft. The mechanical design is based on the GE90 LPT philosophy with the intention to utilize the maximum amount of GE90 hardware. The turbine cross-section is shown in Figure 3.7.1.

The power turbine uses the GE90 flowpath with new vanes and blades. The GE90 LPT secondary flows and temperatures were used for the preliminary estimate of the ATS turbine flows and temperatures which where used for component sizing. The disks have been sized for ATS operating conditions (3600rpm) and 100,000 hours creep life.

The turbine mid frame and the rear frame haye been adopted for the GE90 design with minimum modification. To ensure the use of the GE90 LPT case, the axial distance between the two frames has not changed. Instead, spacers have been added to the flowpath, because the ATS turbine has one fewer turbine stage than the GE90.

The bearing sump and rotor thrust balance design is similar to the GE90 design with the exception that an additional bearing has been incorporated to support the new power output shaft.

\section{Turbine Airfoil Material Selection}

For initial assessment of the material requirements for the LPT blades, the stress and temperature regime for each stage was established and compared to the $0.2 \%$ average creep life capability for a series of candidate turbine airfoil alloys. The goal life for LPT blades is 50,000 hours minimum, a period of time for which materials data does not exist for most of these alloys; this required extrapolation and estimation to project the long time materials capability. Based on prior experience, the physical metallurgy of these materials, and the temperature range of the estimate, we expect these estimates to be accurate.

The $0.2 \%$ creep requirement is a standard, but conservative, criteria first step design assessment which, if met, provides a product component with substantial deformation margin (is not deformation limited) which usually lasts the product lifetime or is refurbished due to long time environmental effects. If the criteria is not met, then the designer moves to another step and conducts further analytical work to calculate detailed creep deformation for the airfoil and assess this result against configuration requirements; tuning the airfoil configuration to reduce stress in limiting areas may be part of this step in the process. Typically, for a machine this size, total radial creep of 20 mils for Stage 1 to 30 mils for Stage 2 represent acceptable limits. This report covers only the initial step in this life assessment process. 


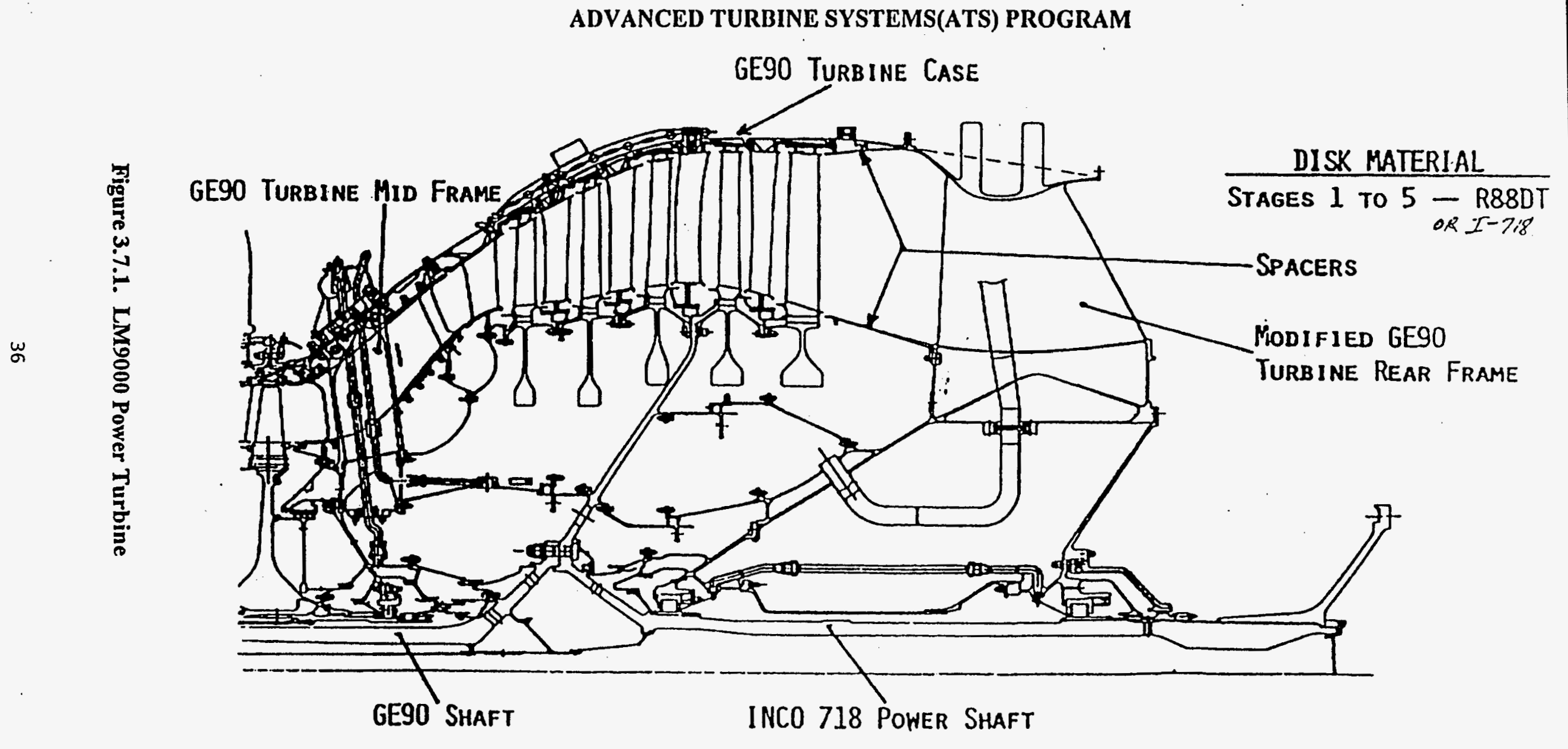


Table 3.7.1

LPT Blades - Temperature Study Regime and Stress Requirements $\mathrm{X}$ - Denotes Temperature Regime

$\underline{\text { Stage }} \underline{\underline{\text { Stress }}} \quad \underline{1800 \mathrm{~F}} \quad \underline{1700 \mathrm{~F}} \quad \underline{1600 \mathrm{~F}} \quad \underline{1500 \mathrm{~F}} \quad \underline{1400 \mathrm{~F}} \quad \underline{1300 \mathrm{~F}} \quad \underline{1200 \mathrm{~F}} \quad \underline{1100 \mathrm{~F}} \quad \underline{1000 \mathrm{~F}} \quad \underline{900 \mathrm{~F}}$ (Ksi)

$\begin{array}{lllllllllllll}1 & 17 & X & X & X & & & & & & & \\ 2 & 30 & & X & X & X & & & & & \\ 3 & 37 & & & X & X & X & & & & \\ 4 & 39 & & & & & X & X & X & & & \\ 5 & 43 & & & & & & & & X & X & X\end{array}$

LPT Blades Temperatures (F) for 2700F T41 and 2600F T41

\begin{tabular}{cccc} 
Stage & Stress (Ksi) & $\frac{2700 F \text { T 41 }}{1700}$ & $\frac{\text { 2600F T41 }}{1600}$ \\
\cline { 2 - 3 } & 17 & 1560 & 1450 \\
3 & 30 & 1420 & 1320 \\
4 & 37 & 1230 & 1140 \\
5 & 43 & 1090 & 990
\end{tabular}

A range of temperatures was studied to correlate with the various ATS cycles under study and display the influence of varying temperature and stress on component life as shown in Table 3.7.1. Material capability in terms of $0.2 \%$ creep life was assessed for cast nickel-based turbine blade alloys used by GE. These alloys are listed below:

$\begin{array}{ll}\text { Alloy } & \text { Form } \\ \text { R77 } & \text { Conventionally Cast } \\ \text { R80 } & \text { Conventionally Cast } \\ \text { In738 } & \text { Conventionally Cast } \\ \text { GTD111 } & \text { Conventionally Cast } \\ \text { R125 } & \text { Conventionally Cast } \\ \text { R108 } & \text { Directionally Solidified - Multi Grain } \\ \text { R142 } & \text { Directionally Solidified - Multi Grain } \\ \text { RN4 } & \text { Directionally Solidified - Single Crystal } \\ \text { RN5 } & \text { Directionally Solidified - Single Crystal } \\ \text { RN6 } & \text { Directionally Solidified - Single Crystal }\end{array}$

Average $0.2 \%$ creep lives were calculated for each alloy for the temperature regime $(3 \times 100 \mathrm{~F}$ increments) and stress condition of each LPT Blade Stage, plotted as bar charts and compared with the 50,000 hour life goal for these components. The following four charts present the results of the analysis for Stages 1 through 4, respectively. The Stage 5 analysis indicated lives greater than 1,000,000 hours for all the alloys considered for temperatures of $1100 \mathrm{~F}$ and lower and no chart is presented for this situation. 


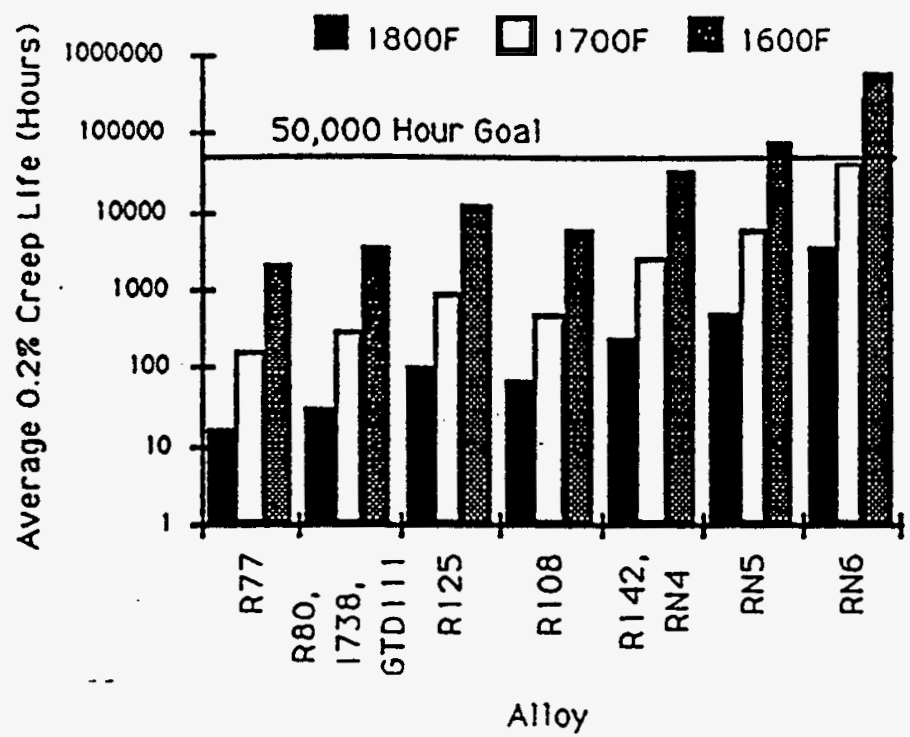

ATS GE LM9000 Stage 2 LPT Blade

Study-0.28 Creep Life at $30 \mathrm{Ksi}$

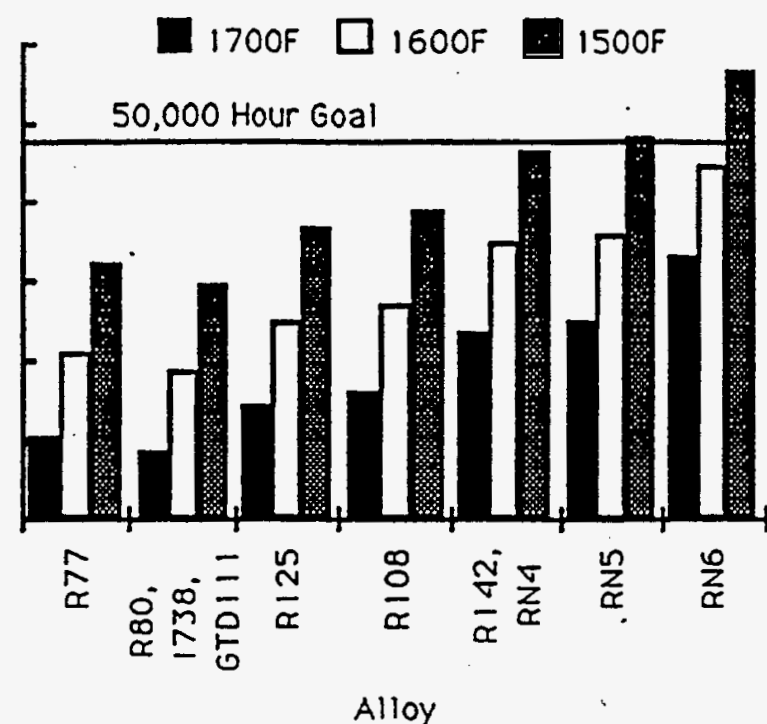

Review of the chart for the Stage 1 LPT blade indicates at 1800F none of the alloys meet the 50,000 hour $0.2 \%$ creep criteria. At 1700F, RN6 comes close with 42,000 hour capability, and at $1600 \mathrm{~F}$, both RN5 and RN6 exceed the requirement. The chart for Stage 2 shows that, although the temperature regime is lower, the increased stress level causes a similar situation as Stage 1, with no alloys meeting the criteria at both $1700 \mathrm{~F}$ and $1600 \mathrm{~F}$, but RN5 and RN6 satisfy needs at $1500 \mathrm{~F}$.

ATS GE LM9000 Stage 3 LPT Blade

study -0.28 Creep Life at $37 \mathrm{Ks}$

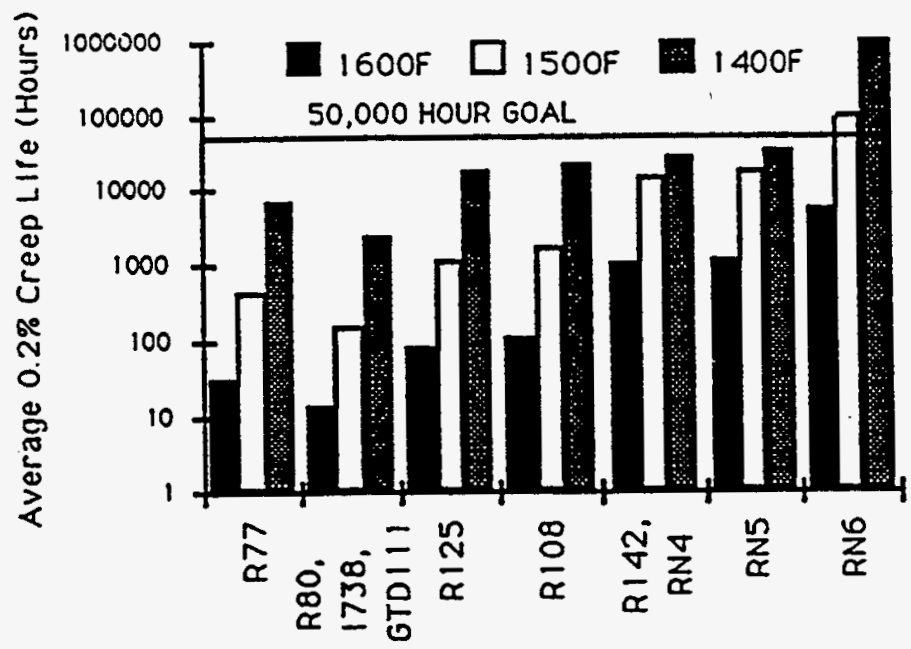

Alloy
ATS LM9000 Stage 4 LPT Blade Study 0.28 Creep Life at $39 \mathrm{Ksi}$

- 1400F I300F 1200F

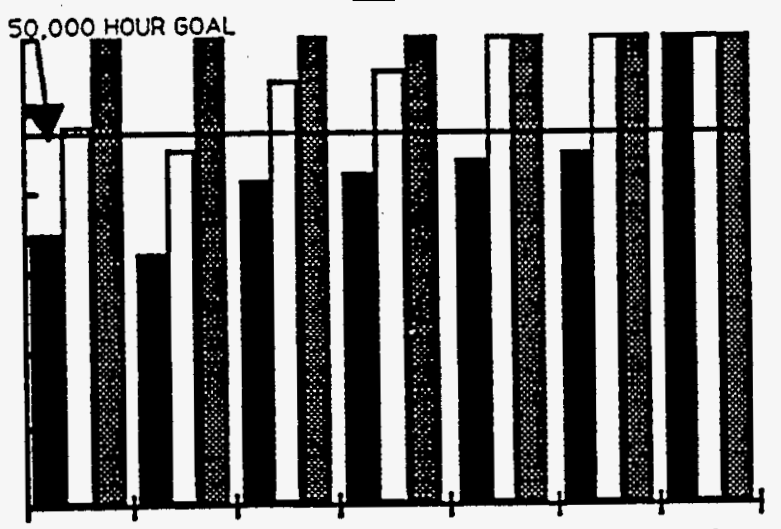

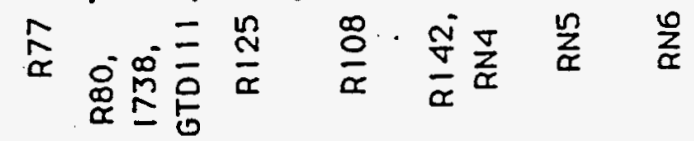

Alloy

Review of the chart for the Stage 3 stress again shows the deformation-free criteria not to be met by any alloy until the temperature is around $1500 \mathrm{~F}$, where RN6 would be fully satisfactory. For Stage 4, conventional cast alloys should be capable of meeting the deformation free criteria with the temperature below $1300 \mathrm{~F}$ at $2700 \mathrm{~F}$ T41. Stage 5 is not creep limited with any of the alloys. 
The overall conclusions are that for the low pressure turbine design:

1. LPT Stages 1,2,3 are creep deformation limited and may require DS/Single crystal alloys to meet life along with detailed deformation analysis and stress tuning to maintain an uncooled LPT airfoil system.

2. LPT Stages 4 and 5 material capability requirements can be satisfied with conventionally cast materials.

\subsection{OVERALL SUMMARYICONCLUSIONS}

After continued studies, a cycle configuration that had the potential to achieve the required program goals was obtained. Key differences of this cycle compared to Configuration 4, which was studied earlier, are as follows:

- Intercooling- Added to allow higher cycle pressures while minimizing the increase in compressor discharge temperature while helping to increase the power output needed to meet the program economic goals.

- Higher cycle pressure ratio which helps to achieve a higher simple cycle efficiency

- Reduced cooling flows, which are a result of lower compressor discharge temperatures.

Based on the changes as noted, an intercooled,turbocooled gas turbine design was carried into Task 6 for concept development. Figures 3.8.1 and 3.8.2 outline the key attributes of this new cycle.

\section{Steam Cycle}

The steam cycle used for the calculation of the combined cycle performance has the following characteristics:

- A three-pressure boiler with reheat and hydrogen cooling.

- Fuel lower heating value (LHV) of $19,000 \mathrm{Btu} / \mathrm{lb}$.

The overall combined cycle performance is shown in Table 3.8.1. The schematic for the steam cycle is shown in Figure 3.8.3. 


\section{GE ADVANCED INTERCOOLED ATS CYCLIE}

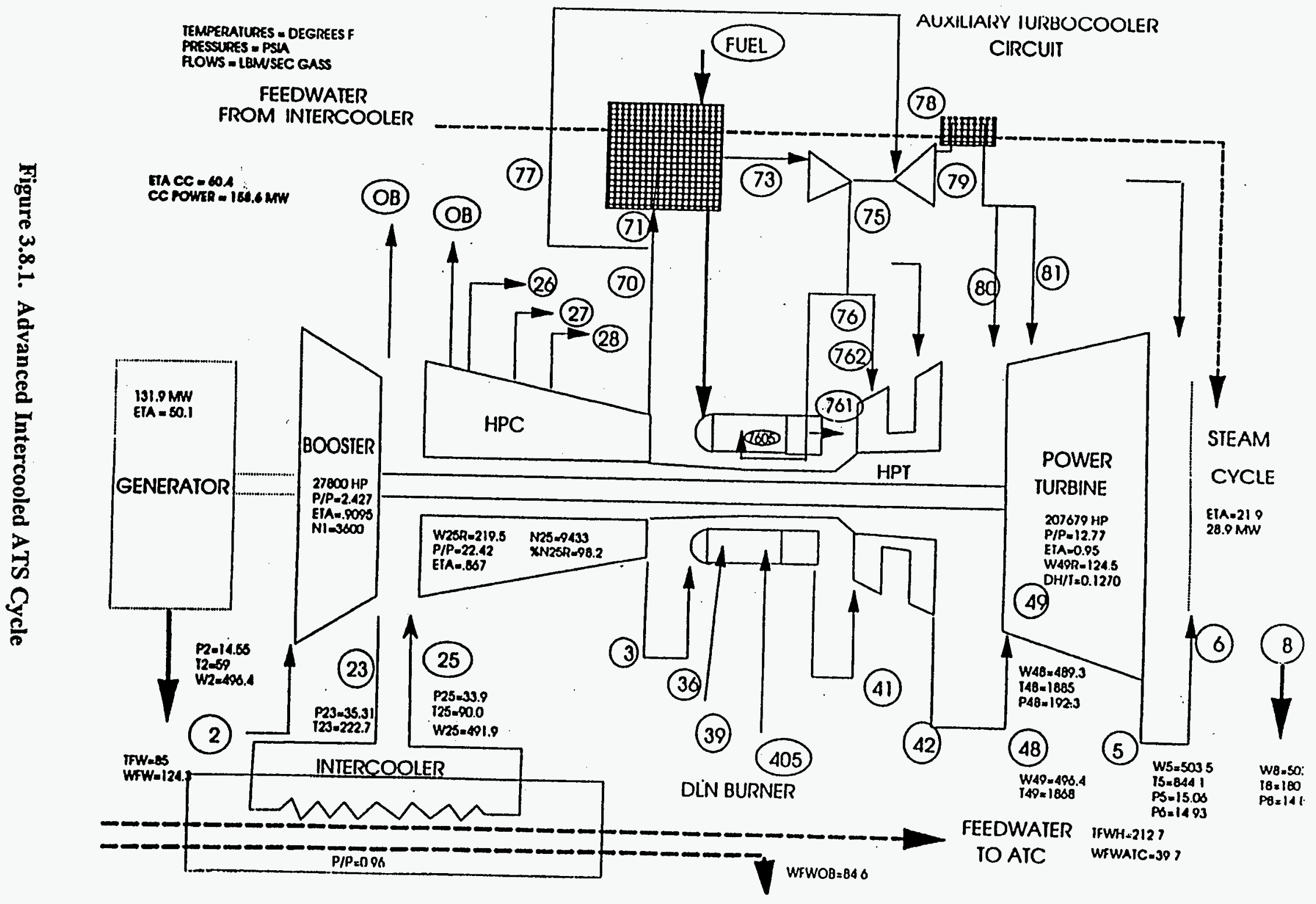




\section{GE ADVANCED INTERCOOLED ATS CYCLE}

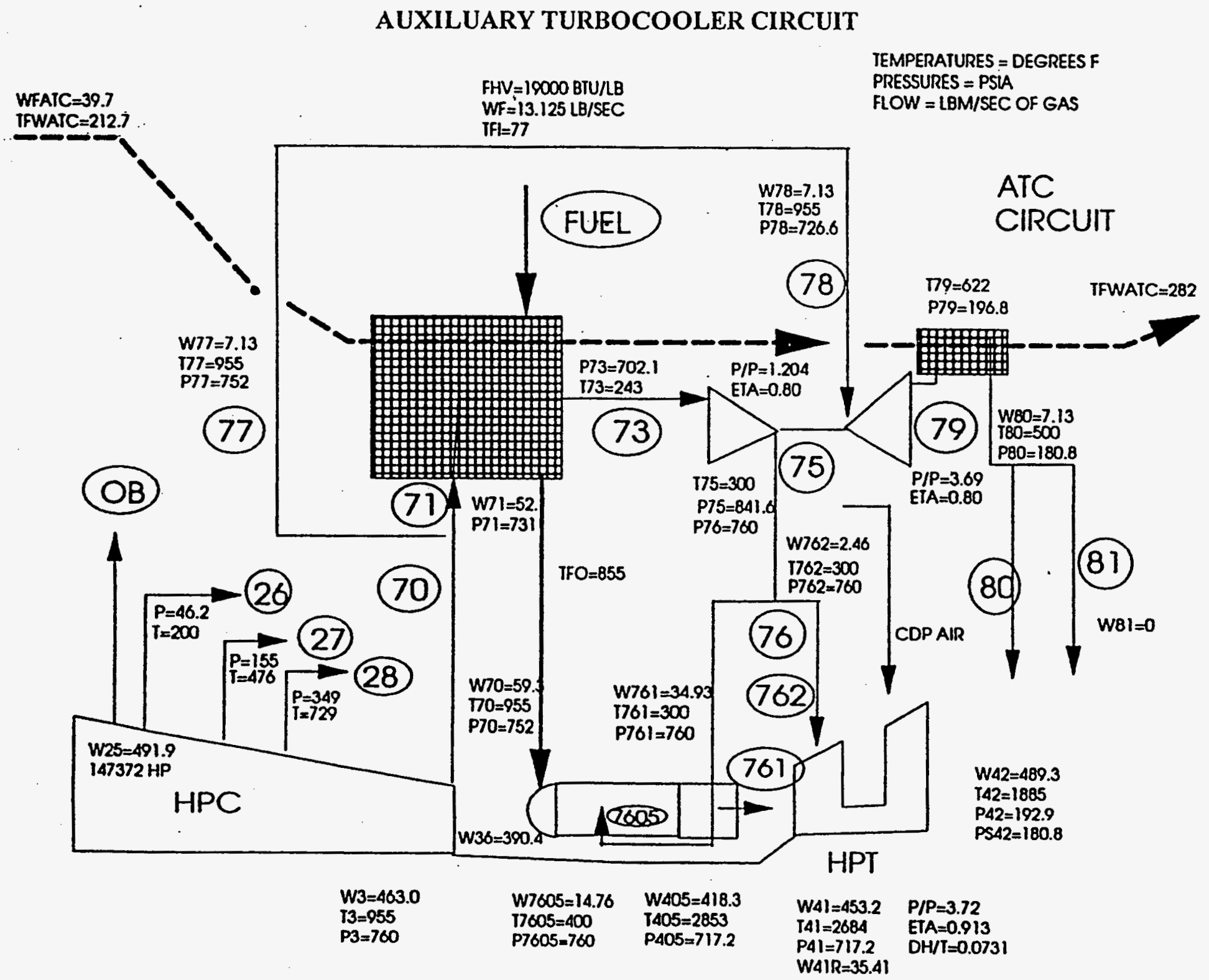

Figure 3.8.2. Auxiliary Turbocooler Circuit 
TABLE 3.8.1

ATS Combined Cycle Performance Summary

\begin{tabular}{|c|c|c|}
\hline Item & Units & Value \\
\hline Gross Gas Turbine Shaft Power & $\overline{\mathrm{KW}}$ & 134,279 \\
\hline Gross Steam Turbine Shaft power & $\mathrm{KW}$ & 28,937 \\
\hline Gross Shaft Power & KW & 163,216 \\
\hline Gross Generator Power & $\mathrm{KW}$ & 160,236 \\
\hline Gas Turbine Heat Consumption & Mbtu/hr & 895.89 \\
\hline Gross CC Heat Rate & Btu/KW-hr & 5,591 \\
\hline Gross CC Efficiency & $\%$ & $61.04 \%$ \\
\hline Equipment and BOP Auxiliaries & KW & 1,600 \\
\hline Net Generator Power & KW & 158,835 \\
\hline Net CC Heat Rate & Btu/KW-hr & 5,647 \\
\hline Net CC Efficiency & $\%$ & $60.43 \%$ \\
\hline
\end{tabular}

Notes:

(1) Includes heating of feedwater to $210.33 \mathrm{~F}$ by gas turbine intercooler air.

(2) Includes addition of 2,471 Btu/sec of heat to feedwater from fuel heating / cooling air cooling system.

(3) Includes addition of $226 \mathrm{Btu} / \mathrm{sec}$ of heat to feedwater from air turbocooler exhaust gas cooling system.

(4) Assumed generator loss for both turbines is $1.76 \%$

(5) Fuel pumping losses for the gas turbine fuel is not included. 


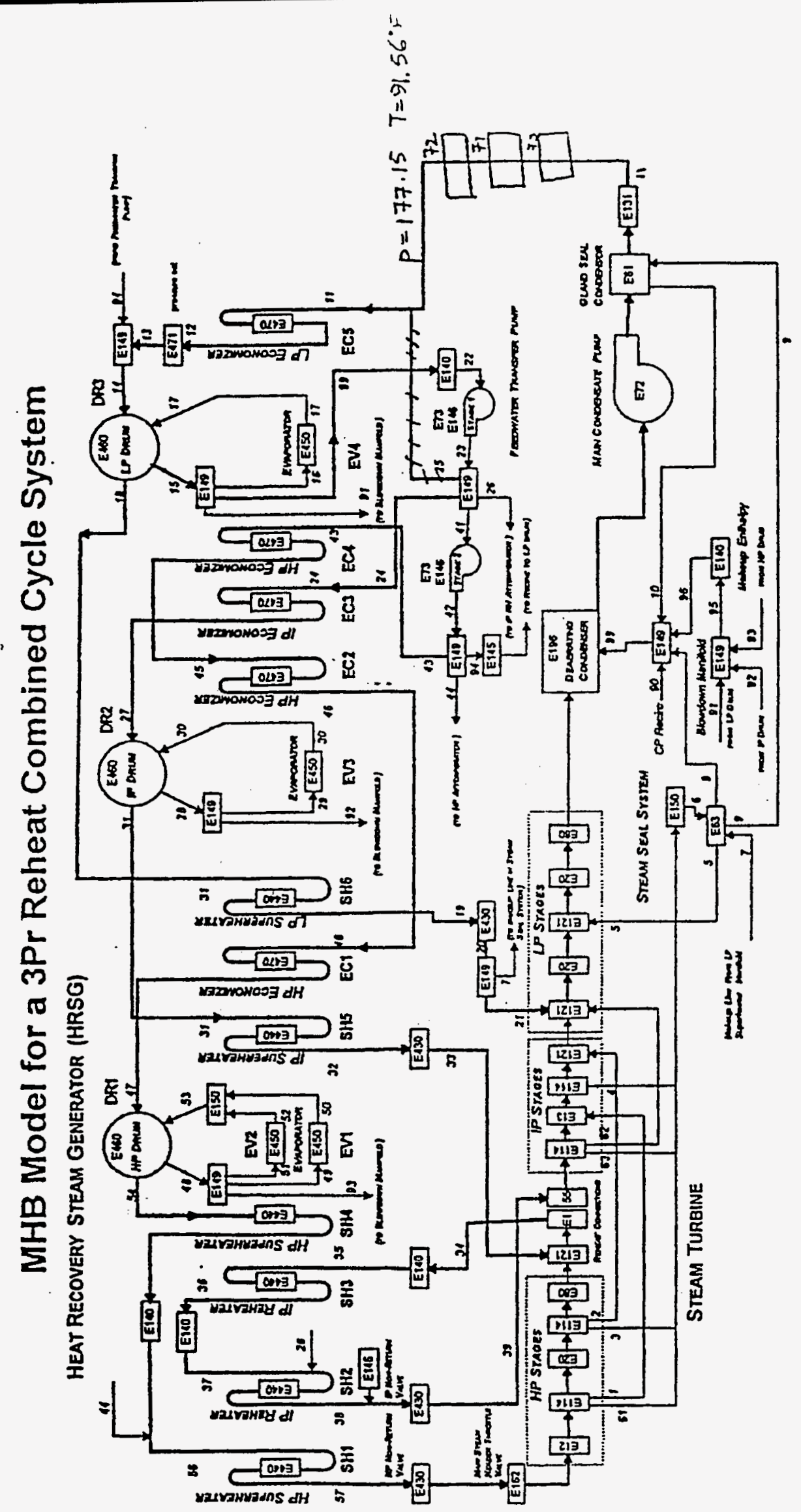

Figure 3.8.3. Steam Cycle Schematic 
M98002026

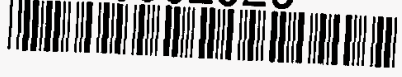

Report Number (14) DOE/mC/30244--5821

subl. Date (11) 199705

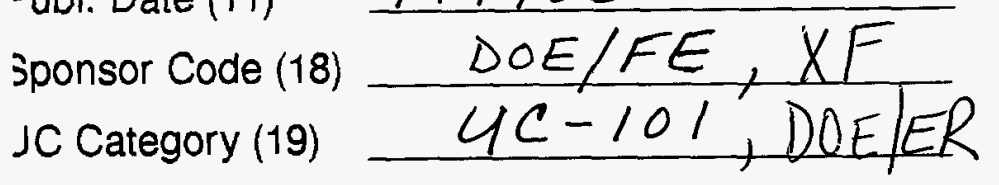

DOE 